\title{
Housing market stability, mortgage market structure, and monetary policy: evidence from the euro area
}

Article

Accepted Version

Creative Commons: Attribution-Noncommercial-No Derivative Works 4.0

Zhu, B., Betzinger, M. and Steffen, S. (2017) Housing market stability, mortgage market structure, and monetary policy: evidence from the euro area. Journal of Housing Economics, 37. pp. 1-21. ISSN 1051-1377 doi:

https://doi.org/10.1016/j.jhe.2017.04.001 Available at https://centaur.reading.ac.uk/72854/

It is advisable to refer to the publisher's version if you intend to cite from the work. See Guidance on citing.

To link to this article DOI: http://dx.doi.org/10.1016/j.jhe.2017.04.001

Publisher: Elsevier

All outputs in CentAUR are protected by Intellectual Property Rights law, including copyright law. Copyright and IPR is retained by the creators or other copyright holders. Terms and conditions for use of this material are defined in the End User Agreement.

www.reading.ac.uk/centaur 
Central Archive at the University of Reading

Reading's research outputs online 


\title{
Housing Market Stability, Mortgage Market Structure, and Monetary Policy: Evidence from the Euro Area
}

\author{
Bing Zhu, Michael Betzinger ${ }^{\dagger}$ Steffen Sebastian ${ }^{\ddagger}$
}

\begin{abstract}
This paper investigates how monetary policy stance and mortgage market structure affect nonfundamental house price movements in eleven Euro area countries. Based on a three-stage approach, our empirical evidence suggests that a one-time monetary-easing shock can significantly trigger house price booms in Euro area countries with liberal mortgage markets. Such shocks can explain over $20 \%$ of the forecasting error variance of non-fundamental house price runups in Ireland and Spain. We find that, in countries with more regulated mortgage markets, monetary policy stance does not significantly affect non-fundamental house prices. Policymakers may wish to focus on limiting mortgage equity withdrawals and on monitoring loan-to-value ratios and tax policies in order to minimize the side effects of accommodative monetary policies on housing market stability for Euro area countries. We posit that this is especially true for peripheral countries, which are more likely to be subjected to overly loose monetary policy stances.
\end{abstract}

Keywords: House prices, Taylor rate, non-fundamental house price, mortgage market structure.

JEL classification: E4, R3.

\footnotetext{
${ }^{*}$ Department of Land Economy, University of Cambridge. 16-21 Silver Street, Cambridge CB3 9EP. Bz262@cam.ac.uk

${ }^{\dagger}$ International Real Estate Business School, University of Regensburg. Universitätsstr. 31, 93053 Regensburg. michael.betzinger@stud.uni-regensburg.de

${ }^{\ddagger}$ International Real Estate Business School, University of Regensburg. Universitätsstr. 31, 93053 Regensburg. steffen.sebastian@irebs.de.

Acknowledgments: The authors thank the editor, the anonymous referee, Jose A. Carrasco-Gallego, John Clapp, Pedro Gete, Gabriel Lee, Rolf Tschernig, Daniel Weber, and the participants in the Lunch Seminar at the University of Regensburg, ReCapnet Real Estate Symposium, European Real Estate Society Annual Meeting and the American Real Estate and Urban Economics National Meeting for useful suggestions on previous versions of the paper. The authors alone are responsible for any errors.
} 


\section{Introduction}

[...] Even more so in a monetary union where vulnerability identified in each country can be addressed with macro-prudential policy, allowing for the appropriate heterogeneity, while countries remain subject to a single monetary policy. [...], macro-prudential policy provides monetary policy with additional room for manoeuvre to better focus on ensuring price stability.

- Vítor Constâncio, ECB Speech, 2015

The last few decades have seen a certain 'de-linking' of short-term house price dynamics from fundamental factors such as income. Non-fundamental house prices dominate short-term movements in house prices and can lead to massive boom and bust cycles. This became vividly apparent over several real estate bubbles in the past decade. Residential investment comprises a large percentage of national wealth and is thus key to general business conditions. Furthermore, housing serves an important purpose as collateral for loans. Fluctuations in house values can dramatically affect the performance of leveraged financial institutions. Therefore, besides being dangerous and costly, such fluctuations are also likely to be the source of economic vulnerabilities and crises (Reinhart and Reinhart (2008); Reinhart and Rogoff (2008)).

The relationship between monetary policy and asset market stability is always somewhat of an open question. This issue is of particular importance for a monetary union where all countries are subject to a common monetary policy, because as long as the local economy is different, the common monetary policy could be too loose for some countries and too tight for the others. For example, Rubio and Carrasco-Gallego (2015a) illustrate how a common monetary policy can ultimately be too loose for the periphery and too tight for the core as the domestic demand growth was extremely strong at the periphery but very weak at the core. Such differences in the monetary policy stance have led to varying housing market movements in EMU countries (Seyfried (2010)). As we experienced over the first decade of the 21st century, inflation has been muted in most countries but real house prices exhibited very different developmental paths. For example, some Eurozone countries, such as Spain and Ireland, experienced unprecedented booms, which arguably can be contributed to the overly loose monetary policy stances. In contrast, other countries, such as Germany and Austria, saw very little price movements over the same time period. As Bernanke (2010) addressed, "[...], differences across countries in inflation and output gaps imply that the degree of policy accommodation relative to economic conditions in each country can differ. [...] Of course, all else equal, a strong economy, even if its strength is unrelated to monetary policy, should experience more robust house prices."

Common monetary policies also limit how they can be used for stabilization purposes. Because bubbles may not materialize in every member country, a 'lean against the wind' strategy may be effective for preventing the bubble in one country while triggering a recession or at least slower growth in other countries Allen and Rogoff (2011)). Therefore, a successful implementation of such a strategy may be difficult in the Euro area. We posit that policymakers should choose policy 
instruments at the national level - macro-prudential policies. Hence, this paper also aims to evaluate the effectiveness of macro-prudential policies for preventing housing bubbles in the Euro area.

We note that most related research in this field is based on major OECD countries (see, e.g., Tsatsaronis and Zhu (2004); Giuliodori (2004); Calza et al. (2013); Sá et al. (2014); Iacoviello and Neri (2010); Bauer (2014)). Results from studies focusing on OECD countries may not be directly applicable to euro area countries, because of, e.g., the heterogeneous banking systems in OECD countries. For example, in the 2000s, market-based financial intermediates held more than $60 \%$ of mortgages in the U.S. (Shin (2009) ) while depository banks are the dominant mortgage holders in most European countries until today. Consequently, the traditional bank lending channel may be less effective in the U.S. as the emergence of market-based financial intermediaries allows banks to be dependent on insured deposits for funding. Additionally, Euro area countries are also subject to fixed exchange rates. Rubio (2014) shows that fixed or managed exchange rates may amplify house price responses to policy shocks in countries that are not small or homogeneous enough. Therefore, OECD countries may not be appropriate samples for studies on how monetary policy stance affects housing market stability in EMU countries.

An analysis of EMU countries has received increasing attention. Based on a DSGE model, Rubio (2014) shows that the heterogeneous mortgage market structure leads to a different response to monetary policy shocks. Under a similar theoretical framework, Rubio and Carrasco-Gallego (2015a) show that a common monetary policy would be associated with an increase in liquidity at the periphery. It can also explain the increase in house prices and stronger credit growth in the peripheral economies during the pre-crisis period.

However, empirical evidence remains limited. Maclennan et al. (1998) focus on EMU countries, and find that those with fixed interest rates, low loan-to-value (LTV) ratios, high transaction costs, and a smaller owner-occupied sector tend to experience lower house price changes. Annett (2006) finds a significant impact of monetary policy on house prices in EMU countries only for France, Ireland, Belgium, Finland, and Spain, but not for the panel.

Our paper empirically investigates the potential adverse impact of a single monetary policy on the stability of the housing market for individual EMU countries. So far, as we searched, this topic has not been studied. Specially speaking, our paper differs from the aforementioned literature in three primary ways. First, we focus on the stability of housing markets and study the impact of monetary policy stance on non-fundamental runups. When observed house prices fluctuate to a greater degree than fundamental factors would normally suggest, non-fundamental factors can lead to additional price volatility. This can have a potentially serious impact on financial stability (Hott (2014)), and, therefore, deserves more attention from policymakers.

Second, even though all euro area countries are subject to a single monetary policy, the individual policy stances are essentially different. Thus, simply using the short-term interest rate fails to capture important differences in the monetary policy stance. In order to address this issue, we use the deviation from the Taylor rule rate as a proxy for the monetary policy stance. The Taylor rule rate can be used to measure an adequate target rate for each individual EMU country 
(Nechio (2011); Kaefer (2014); Bjoerksten and Syrjaenen (2000)). For example, Allen and Rogoff (2011) and Scantee and Stoica (2013) show that the Taylor rule rate would imply that the ECB's monetary policy is essentially too loose for some countries, while completely appropriate for others. As a result, the ECB rate may have a destabilizing effect on GDP and inflation in countries with significant deviations from the Taylor rule rate. Although the impact of short-term interest rates on house prices has been studied extensively in the literature, empirical evidence for the impact of deviating from the Taylor rule rate on housing market stability for EMU countries remains limited.

Third, we examine whether macro-prudential policy can successfully help policymakers to eliminate the side effects of deviations from the Taylor rule rate, which is inherent to the common monetary policy for EMU countries in the current stage. We adopt an interacted panel VAR model to quantify the impact of institutional factors on the responses of non-fundamental house price runups to a monetary-easing shock. This approach compares the impact of monetary policy without splitting country samples, and it allows for time-varying mortgage market characteristics. Most of the previous literature has studied the impact of mortgage markets by splitting country samples. However, this may ignore the role of time-varying mortgage market characteristics. For example, in the early 2000s, many countries increased their maximum LTV ratios. During the subsequent crisis period, the maximum LTV ratio decreased slightly in those countries. Therefore, we expect to see variations in the VAR coefficients.

Our results show that monetary policy stance can trigger significantly non-fundamental house price overshooting in euro area countries with liberal mortgage markets. Peripheral countries are more sensitive to interest rate gap shocks. Mortgage market characteristics also play a critical role in the transmission of monetary policy at the periphery. A one-time positive shock to the interest rate gap can explain over $20 \%$ of the forecasting error variance of non-fundamental house price runups in Ireland and Spain.

In housing markets with less liberalized mortgage markets, we observe more limited responses of the non-fundamental house price component to interest rate shocks. Thus, policymakers may wish to focus on limiting mortgage equity withdrawals, monitoring loan-to-value ratios, and avoiding the exaggerated use of tax policies. Macro-prudential policies are able to minimize the side effects of accommodative monetary policies on housing market stability for peripheral countries that are more likely to be subject to overly loose monetary policies.

\section{Literature Review}

Our paper is built upon several interrelated strands of the literature. Regarding the interdependence between monetary policy and house price movements, many studies have found that monetary policy significantly affects house prices, especially when it is too liberal. Indeed, house price booms are typically preceded by periods of loose monetary policy (Dokko et al. (2011); Seyfried (2010); Ahearne et al. (2008); Simo-Kengne et al. (2013); Taylor (2007); Greiber and Setzer (2007); Jarocinski and Smets (2008); Antipa and Lecat (2009); Escobari et al. (2013)). Monetary policy 
can affect house prices through several channels. The primary one is the interest rate channel. Given price stickiness, an increase in nominal interest rates translates into an increase in users' cost of capital, which in turn leads to a reduction in investment spending and a decrease in housing demand (Goodman and Thibodeau (2008)). Moreover, studies by Bernanke and Blinder (1992) and Disyatat (2011) show that monetary policy shocks can be transmitted to the housing market through the credit channel. For example, a shock that tightens monetary policy can impact banks by decreasing their loan supply and borrowers' net worth (Aoki et al. (2004); Iacoviello (2005)), and/or by inducing banks to tighten their reserve requirements (Bernanke and Blinder (1992)). Monetary policy can also affect house prices by changing investor risk perceptions. Thus, lower interest rates may result in lower risk premiums, either because of a decrease in perceived risk or because of an increase in risk tolerance (Adrian and Shin (2008); Adrian et al. (2012)).

The key issue here is how to identify a monetary policy shock. Most of the literature uses shortand/or long-term interest rates. Other research, however, such as Sá et al. (2014), imposes sign restrictions on the impulse responses to identify a shock. A third strand uses the Taylor rule rate. First proposed by Taylor (1993), it stipulates how much a central bank should change its nominal interest rate in response to changes in economic fundamentals such as inflation and GDP. Gerlach and Schnabel (2000) demonstrate that interest rate policies in European countries move very closely with output gaps and inflation which supports the applicability of the Taylor rule concept. Using Taylor's rule as a benchmark, Seyfried (2010) found that monetary policy was too loose in several countries prior to the bursting of their respective housing bubbles, including Ireland, Spain, and the U.S. Seyfried (2010) also found that monetary policy was appropriate or slightly restrictive for France and Germany, which did not exhibit any housing bubbles over the same period. Using a panel logit framework, Bauer (2014) estimates the likelihood of a house price correction in eighteen OECD countries. Using the Canadian housing market as an example, the results show that a sharp tightening of interest rates can trigger a house price correction. Hott and Jokipii (2012) regress non-fundamental house price changes of fourteen OECD countries on a deviation of the Taylor rule rate, and find a strong link between housing bubbles and low interest rates. The impact is stronger when the interest rate is "too low for too long." However, although monetary policy is a major determinant of house price movements, other factors remain highly relevant. Note that the reaction of house price inflation has been found to differ across regions with a common monetary policy (Barigozzi et al. (2014); Rubio (2014)). Some studies assess the drivers behind country- and region-specific differences in real estate markets, and explore the importance of mortgage market heterogeneity for monetary policy transmission. For example, based on OECD countries, Adams and Füss (2010) find that varying housing market dynamics can be traced back to differences in national regulatory settings and mortgage market features. Muellbauer and Murphy (1997) and Iacoviello and Minetti (2003) argue that the financial liberalization of mortgage markets led to a significant increase of house price sensitivity to short-term interest rates for the U.S. and the U.K. Milcheva and Zhu (2015) study seventeen OECD countries, and show that countries with more developed mortgage markets are more sensitive to international house price comovements. 
The argument that more flexible mortgage market structures provide more robust monetary policy transmission is supported further by Calza et al. (2013) using DSGE models. Rubio and Carrasco-Gallego (2015b) and Rubio (2014) focus on household leverage. They show that the loan-to-value ratio is an important determinant of house price increases. Based on a twocountry monetary union DSGE model, Rubio and Carrasco-Gallego (2015a) study how a house price shock in peripheral countries and a technology shock in core countries are transmitted to both economies. In an empirical study, Maclennan et al. (1998) compare the house price movements of EU-15 countries and show that the divergent developments can be explained by institutional differences between the mortgage markets, including interest rate type, LTV ratios, transaction costs, and the size of the owner-occupied sector.

\section{Econometric Modelling}

To estimate the relationship between non-fundamental house prices and monetary policy stance, as well as the influence of the mortgage market, we use a three-stage estimation strategy. First, we estimate non-fundamental house price runups, defined as the residuals of observed house price changes and the respective fundamental part. We can predict fundamental house price changes by using local housing demand and supply factors. Second, we use the deviation of the short-term interest rate from the Taylor rate level in each country in order to proxy for monetary policy in the individual countries. Third, we investigate the impact of monetary policy on house price runups using an interacted panel VAR setting, conditional on mortgage market developments in each country.

\section{A. Non-Fundamental House Price Runups}

To estimate for our first stage, we note that monetary policy can affect house prices by changing users' costs. This impacts the fundamental value of housing assets. However, additional deviations may occur because of investors' speculative behavior and optimistic expectations. Because nonfundamental deviations may result in market instability and in asset price fluctuations, we are particularly interested in how monetary policy impacts non-fundamental price runups.

As per Equation (1), and following Dipasquale and Wheaton (1994), Case and Shiller (2003), Goodman and Thibodeau (2008), Gallin (2006), Muellbauer and Murphy (2008), and Koetter and Poghosyan (2010), we can define a countrys demand for housing $\left(Q^{D}\right)$ as a function of household income $(Y)$, the price of rental housing services $(R)$, and market size, measured as population $(P O P)$.

The price of rental housing services equals users' costs $(\rho)$, which are positively correlated with the mortgage rate $(M r)$, asset depreciation $(d)$, and the property tax rate $(t r)$, and negatively correlated with the product of expected capital gains $E\{p\}$ and house value $(V)$. From the supply side, the aggregate quantity of house supply can be a function of asset price $(V)$ and supply shift 
$(G)$.

$$
\begin{gathered}
\ln Q^{D}=\alpha_{1} \ln Y+\alpha_{2} \ln R+\alpha_{3} \ln P O P \\
\ln R=V[M r+d+t r-E\{p\}] \\
\ln Q^{S}=\alpha_{4} \ln V+\sum_{j=1}^{J} \alpha_{5, j} G_{j}
\end{gathered}
$$

In the product market equilibrium, $\ln Q^{D}=\ln Q^{S}$. Solving Equation (1), we obtain:

$$
\ln V=\vartheta_{1} \ln Y+\vartheta_{2} \ln \rho+\vartheta_{3} \ln P O P+\sum_{j=1}^{J} \vartheta_{4, j} G_{j}
$$

The fundamental house price $\left(P^{f}\right)$ is the long-term equilibrium price based on Equation (2). In the empirical section, we define non-fundamental house price runups as the deviation of observed house price changes $(P)$ from the respective fundamental price changes. We estimate the fundamental price for each country individually.

According to Equation (2), changes in the fundamental house price in country $i$ at period $t$ are based on the changes in a set of local demand and supply determinants, including $G D P$, inflation $(C P I)$, population $(P O P)$, disposal personal income (Income), housing permits (Permit), and the mortgage rate $(M r)$. As the depreciation rates and property tax rates remain unchanged over time in many countries, they are captured by the constant term $\left(\alpha_{i}\right)$ in our regression estimation. Considering the endogeneity problem between demand/supply factors and the house price, we use the lagged variables to estimate the fundamental price:

$$
\begin{aligned}
\Delta \ln P_{i, t}= & \alpha_{i}+\sum_{p=1}^{4} \beta_{1 i, p} \Delta \ln G D P_{i, t-p}+\sum_{p=1}^{4} \beta_{2 i, p} \Delta \ln C P I_{i, t-p}+\sum_{p=1}^{4} \beta_{3 i, p} \Delta \ln P O P_{i, t-p} \\
& +\sum_{p=1}^{4} \beta_{4 i, p} \Delta \operatorname{lnIncome} \operatorname{In}_{i, t-p}+\sum_{p=1}^{4} \beta_{5 i, p} \Delta U E_{i, t-p}+\sum_{p=1}^{4} \beta_{6 i, p} \Delta \ln \text { Permit }_{i, t-p} \\
& +\sum_{p=1}^{4} \beta_{7 i, p} \Delta M r_{i, t-p}+e_{i, t}^{h p}
\end{aligned}
$$

where $\alpha_{i}$ and $\beta_{i}$ are the coefficients for country $i$. The estimation of the fundamental price includes up to four lags 11 The fundamental price change is the predicted price change $\left(\Delta \ln \hat{P}_{i, t}\right)$ where the non-fundamental price runups are defined as the residuals $\left(e_{i, t}^{h p}\right)$. Considering that elasticity on house prices with respect to fundamental factors can vary across countries, we estimate Equation (3) separately for each country by means of an OLS estimator $2^{2}$

\footnotetext{
${ }^{1} \mathrm{Up}$ to eight lags are tested in total. All specifications yield very similar results.

${ }^{2}$ Using weighted least squares to account for the outliers during the boom periods generates robust results. We also estimate the residuals based on contemporaneous demand and supply factors using the GMM estimator (instrument variables are set as lagged demand/supply variables up to four periods). The results are also robust.

${ }^{3}$ See the online appendix for detailed graphs on fundamental and observed changes.
} 


\section{B. Deviation from Taylor Rule Rate}

In order to proxy for the monetary policy stance of central banks, we estimate the deviation of the short-term interest rate from its Taylor rule level. We can estimate that level in each country by constructing both inflation and output gaps, and then using the deviation of the GDP from its filtered value as an estimate of the output gap. The Taylor rule level of the short-term interest rate is defined as:

$$
r_{i, t}=\gamma_{0, i}+\gamma_{1, i}\left(\pi_{i, t}-\pi_{i}^{*}\right)+\gamma_{2, i}\left(y_{i, t}-y_{i, t}^{*}\right)+e_{i, t}^{T R}
$$

where $r_{i, t}$ is the short-term interest rate, $\gamma_{0, i}$ is the neutral (nominal) interest rate in country $i$, $\pi_{i, t}$ is the actual inflation rate in country $i$ at period $t$, and the starred value indicates the target, which is set at $2 \%$. $\left(y_{i, t}-y_{i}^{*}\right)$ is the output gap, with $y_{i, t}$ for the log-transformed GDP in country $i$ at period $t, y_{i, t}^{*}$ is the filtered series using the Hodrick-Prescott filter (with a smoothing parameter of 1600), and $e_{i, t}^{T R}$ is the difference between the short-term interest rate and the Taylor rate (TR).

Svensson (1999) suggests that the TR equation is the optimal reaction function for a central bank that targets inflaton in a simple backward-looking two-equation model of the economy, and $\gamma_{1}$ and $\gamma_{2}$ are convolutions of policymakers' preferences as well as the parameters in the IS and Phillips curves. Taylor (1993) suggests that $\gamma_{0}=4, \gamma_{1}=1.5$, and $\gamma_{2}=0.5$ for the U.S. market. GerlachKristen (2003) suggests these values may not apply for all countries. Therefore, we estimate the $(\gamma s)$ coefficients separately for each country. Considering the potential endogeneities in Equation (4), we use the GMM estimator including up to four lags of inflation and the output gaps as instrument variables. The fitted value $\left(\hat{r}_{i, t}\right)$ is TR and the residuals $e_{i, t}^{T R}$ are the deviation from TR, which represents a measure of the monetary policy stance $4^{4}$

\section{Impact of Monetary Policy Stance on House Prices}

At this stage, we combine the estimated non-fundamental price changes and the deviation from the Taylor rate into the panel data setting, and incorporate the credit supply into the regression in order to perform an interacted panel VAR model as follows:

$$
X_{i, t}=\Psi_{i}+\Psi^{M} M_{i, t}+\sum_{p=1}^{4} \Phi_{p} X_{i, t-p}+\sum_{p=1}^{4} \Phi_{p}^{M} M_{i, t} X_{i, t-p}+\sum_{p=1}^{4} \Upsilon_{p} Z_{t-p}+\sum_{p=1}^{4} \Upsilon_{p}^{M} M_{i, t} Z_{t-p}+\varepsilon_{i, t}
$$

where $X_{i, t}$ is a $5 \times 1$ vector of the non-fundamental house price change, the deviation from the Taylor rule rate, and the change in domestic total credit to households, current account balance,

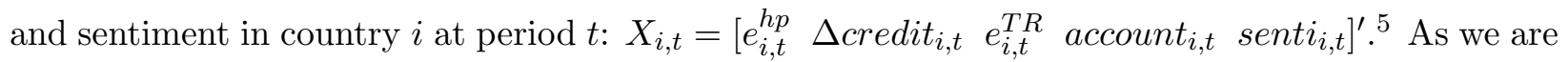
interested in the impact of variable $M_{i}$ on the interdependence of endogenous variables, we hold

\footnotetext{
${ }^{4}$ See the online appendix for detailed information about the fitted Taylor rule rate.

${ }^{5}$ As a robustness check, we substitute the credit gap for the credit growth variable. We calculate the credit gap as the difference between the credit-to-GDP ratio in each country and the corresponding Hodrick-Prescott filtered credit-to-GDP ratio (with a smoothing parameter of 1600). When we use credit gap as a measure of credit supply, the coefficients, the impulse response, and the variance decomposition are very close to the results we obtain based on credit growth.
} 
everything else fixed. $\Psi_{i}$ is the country-specific intercept, $\Phi_{p}$ is the $5 \times 5$ matrix of autoregressive coefficients, the maximum lag is chosen as four based on BIC criteria, $M_{i, t}$ is the mortgage market indicator for country $i$ at period $t$, which measures the mortgage market development of country $i$ at period $t$ relative to other countries and other periods and is standardized at between 0 and 1 , and $\Psi^{M}$ is a $5 \times 5$ diagonal matrix of coefficients.

We consider five indicators: mortgage rate type, mortgage equity withdrawal, maximum loanto-value ratio, mortgage securitization, and an index of government participation. Among the five indicators, mortgage rate type and the index of government participation remain constant over time. If index $M_{i, t}$ is invariant over time, then including both $M_{i, t}$ and country-specific fixed effects leads to perfect multicollinearity. To avoid this problem, we exclude country-specific dummy variables if $M_{i, t}$ is constant over time. If $M_{i, t}$ is variant over time, both $M_{i, t}$ and country fixed effects are included. $\Phi_{p}^{M}$ is a $5 \times 5$ coefficient matrix of the interaction term $\left(M_{i, t} X_{i, t-p}\right)$. The interaction term measures the impact of mortgage market developments on the interdependence of the endogenous variables without splitting the sample.

As presented in section $4, Z_{t}$ is a $3 \times 1$ vector for three global/regional variables in period $t$, which are the same for all countries. They are also interacted with mortgage market indicators. $\Upsilon_{p}$ is a $5 \times 3$ matrix of coefficients for variable $Z$, and $\Upsilon_{p}^{M}$ is a $5 \times 3$ matrix of coefficients for the interaction with the mortgage market indicator. $\varepsilon_{i, t}$ is the $5 \times 1$ vector of error terms and $\varepsilon_{i, t} \sim N(0, \Omega)$, where $\Omega$ is a $5 \times 5$ matrix. This model extends the standard panel VAR model with fixed effects, and takes into account both the intercept and slope heterogeneity. We estimate the coefficients in Equation (5) by using OLS.

The impulse response is essentially based on estimated coefficients $\Phi_{i, p}, \Phi_{i, p}^{M}$ and $\Omega$. The Cholesky decomposition order is the deviation from the non-fundamental Taylor rate, the change in housing credit, account balance, non-fundamental house price changes, and sentiment. The results are fully robust with other order sequences. Because $\Omega_{i, p}^{M}$ may vary across countries, the responses also vary across countries, with that variation dependent on each countrys mortgage market characteristics. We follow Sá et al. (2014) and report the results for $M_{i, t}=0.75$ as the more liberal mortgage market, and $M_{i, t}=0.25$ as the less liberal mortgage market. Therefore, the impulse response function is based on the coefficients $\Phi_{p}^{H i g h}=\Phi_{p}+0.75 \Phi_{p}^{M}$ for more liberal mortgage markets, and on $\Phi_{p}^{\text {Low }}=\Phi_{p}+0.25 \Phi_{p}^{M}$ for less liberal mortgage markets.

\section{Data}

Our sample includes eleven countries: Austria, Belgium, Finland, France, Germany, Greece, Ireland, Italy, the Netherlands, Spain, and Portugal. For the Taylor rate estimation, it was necessary to use a long time horizon, so we use the maximum available time series. Thus, the Taylor rate estimation is based on data going back to the 1980s for some countries. However, we restricted the panel to between the first quarter of 1992 and the fourth quarter of 2012 due to the limited availability of house price data. House price indices are collected from BIS. BIS data was not 
available for Greece and Portugal, though, so we use data from Oxford Economics.

Because our primary focus here is to analyze how monetary policy stance and mortgage market structure influence non-fundamental house price developments, we consider country-specific factors that can be regarded as fundamental demand and supply drivers of house prices. These include real gross domestic product $(G D P)$, credit from domestic banks to the private non-financial sector as a share of GDP, the consumer price index inflation $(C P I)$, total population $(P O P)$, the unemployment rate $(U E)$, disposable personal income (Income), housing permits (Permit), the mortgage rate $(M r)$. GDP, $C P I, U E$, account balance and sentiment data come from OECD. Mortgage rates come from national sources or from the ECB. Credit, population and housing permits come from BIS, Oxford Economics, and Datastream, respectively. In our model, these country-specific variables are expressed in growth rates.

We also include three global factors. The European current unit/Euro to U.S. dollar exchange rate comes from the OECD database. The European current unit was adapted by the eleven countries in 1979, and was later replaced by the Euro. Oil prices come from Datastream. They are a good indicator of global economic cycles and inflation expectations, while financial leverage is a good measure of the global appetite for financial risk. During the financial crisis, we observed global deleveraging (see Shin (2009); Adrian et al. (2012)) which affected the credit supply by reducing interbank flows and hence bank balance sheet size. We follow Bruno and Shin (2014), and measure global financial leverage as the sum of the equity and total liabilities of U.S. broker-dealers divided by their equity. The broker-dealer balance sheet data comes from the U.S. Flow of Funds. Broker-dealer leverage is strongly negatively correlated with the VIX index of implied S\&P stock market volatility, and is thus also likely related to global investor risk appetite. Precise definitions and sources of all variables are in Table A1.

Table A2 provides an overview of the countries' mortgage market indicators. The higher the mortgage market indicator, the more liberal is the respective mortgage market. A liberal mortgage market is characterized by a predominantly variable mortgage rate, the possibility of mortgage equity withdrawals, a high LTV ratio, the existence of a secondary mortgage market, and high government participation. The data for mortgage rate type, mortgage equity withdrawals, maximum LTV ratio, and government participation comes from Tsatsaronis and Zhu (2004) and IMF (2008).

Regarding the degree of mortgage securitization in the mortgage sector, we follow Sá et al. (2014) and use the de jure qualitative securitization index constructed by Hoffmann and Nitschka (2008). This index equals 1 if countries have a fully liberalized MBS market, and 0 if a secondary mortgage market is not permitted by national law or regulation. Although this securitization index does not reflect institutional changes in the ability to securitize mortgage assets, it may help avoid potential endogeneity issues with de facto measures of mortgage-backed securitization. Precise definitions of mortgage market development indicators are in Table A2. 


\section{Results}

\section{A. Non-fundamental House Price Runups}

Our first step is to analyze non-fundamental house price runups. Table A3 reports $\mathrm{F}$ tests for the joint significance of the lagged fundamental factors. Total population can significantly explain house prices in six of the eleven countries. Other factors, such as the mortgage rate and personal income, also play a significant role in many countries. Except for Belgium, Germany, and Austria, the seven fundamental variables can predict more than $50 \%$ of house price variance.

Figure 1 illustrates the maximum cumulative deviation from the fundamental values for all eleven countries. The labels show the respective quarters when the maximum cumulative deviation occurred, with most experiencing it during the mid- to late 2000s and prior to 3Q2007. Stable countries such as Germany (DE) and Austria (AT) are characterized by low deviations in the house price change from the fundamental change; more economically volatile countries, such as Ireland (IE), are characterized by rather large gaps between overall house price changes and underlying fundamental changes. This in turn suggests a large non-fundamental change in house prices. In the case of Ireland, for example, we observe a $13 \%$ maximum cumulative deviation from the underlying fundamental level in the first quarter of 2007. In comparison, in Germany, it was only $2 \%$.

\section{[Place Figure 1 about here]}

\section{B. Deviation from Taylor Rule Rate}

Table A4 presents the estimation results of GMM model. The coefficients are in general similar to those found by Taylor (1993). Figure 2 provides an overview of the average interest rate gaps in the eleven countries, divided into three time periods: 1Q1993-4Q1999, 1Q2000-2Q2007, and 3Q2007-4Q2012. We observe differing degrees and directions of the deviation of the actual interest rate from the respective Taylor rate. A positive deviation means that the Taylor rate is higher than the actual interest rate, which implies a looser monetary policy; a negative deviation implies a more restrictive monetary policy.

As shown in Figure 2, monetary policy was restrictive before 2000, as we can clearly observe positive average interest rate gaps for all countries. In contrast, monetary policy became more relaxed at the beginning of 2000. Thus, there are negative interest rate gaps for all the European countries after 2000 .

When analyzing the European countries, we must account for the fact that they have a common monetary policy as set by the ECB. The ECB generally aims to conduct policies that will be optimal for the EMU as a whole, not just for individual countries. However, because economic fundamentals differ among the European countries (which appears to be an endogenous problem), the ECB's monetary policy would be too loose for some countries, and too restrictive for others (Allen and Rogoff (2011)). In Ireland and Spain, for example, we note that interest rates were too low during the housing boom period when compared to the Taylor rate. In contrast, monetary 
policy appears to have been more restrictive for Austria, Germany, and Finland, where we did not observe any severe misalignments between house prices and their underlying fundamental values.

\section{[Place Figure 2 about here]}

\section{Monetary Policy Transmission}

At the third stage of our estimation approach, we combine the estimated non-fundamental price change and the deviation from the Taylor rate to construct an interacted panel VAR model. The Chow test suggests a significant structural break in 1Q2007 (Table 1). Thus, our estimation runs from 1Q1993 to 2Q2007. After 2007, the ECB adopted unconventional monetary policies.

\section{[Place Table 1 about here]}

Figure 3 shows the impulse responses to the respective shocks. In order to derive conclusions about the role of the mortgage market structure, we compare the response of a country with a developed mortgage market $\left(M_{i, t}=0.75\right.$, in red) to that of a country with a less developed mortgage market $\left(M_{i, t}=0.25\right.$, in black). We measure mortgage market development as the average value of five indicators: mortgage rate type, availability of mortgage equity withdrawal (MEW), maximum loan-to-value (LTV) ratio, degree of mortgage securitization, and government participation index. We forecast the impact from the first through the twentieth quarter after the shock. The results are based on a $90 \%$ confidence interval.

We first analyze the impact of a 1-standard deviation interest rate-easing shock (a negative interest rate shock) based on all Euro area countries. As shown in Figure 3-1, for the interest

rate shock, there is a significant difference in the response of the two mortgage market structures. For the country with a more liberal mortgage market, a negative interest rate shock of 1 standard deviation leads to a maximum increase in the non-fundamental house price of $0.2 \%$ in the third quarter after the shock. This is much more severe than the close to zero response in the country with a less liberal mortgage market. However, the impact of a 1-standard deviation interest rateeasing shock is not persistent, as it disappears within two to three years. Therefore, the impact is mostly relevant in the short term.

The variance decomposition of non-fundamental house price runups, as shown in Table 2, provides further evidence that a more liberal mortgage market is associated with a stronger impact of a monetary impulse. As $M_{i, t}$ increases from 0.25 to 0.75 , the explained variance triggered by the 1-standard deviation shock increases from $0.39 \%$ to $7.38 \%$ of total forecasted non-fundamental house price change.

Figures 3-2 and 3-3 illustrate the impact of an interest rate-easing shock by separating the core and peripheral Euro area countries. Core area countries are Austria, Belgium, Finland, France, Germany, and the Netherlands; peripheral countries are Ireland, Italy, Greece, Spain, and Portugal.

For the core area countries, there is no statistically significant difference in the response of house prices to the monetary-easing shock. The response for all countries is close to zero, irrespective of 
the individual mortgage market structure. The variance decomposition (Table 2, model 2) confirms this observation, as the explained variances of non-fundamental house price movements are $2.32 \%$ and $0.39 \%$ for the more and less liberal countries, respectively.

However, for the peripheral countries, there is a significantly higher response of house prices in the countries with more liberal mortgage markets between the first and fifth quarters after the shock. We observe an increase of up to $0.4 \%$ in the third quarter. These findings are highlighted by the explained variance as illustrated in Table 2, model 3. For the countries with more liberal mortgage markets, the 1-standard deviation monetary-easing shock can explain $24.36 \%$ of the nonfundamental house price movements. In contrast, in less liberal countries, we observe only $1.03 \%$.

\section{[Place Figure 3 about here]}

\section{[Place Table 2 about here]}

Figure 4 illustrates the cumulative one- and three-year impact of a 1-standard deviation shock to the interest gap for the core and peripheral countries. Figures 4-1 and 4-2 show the cumulative response and the explained variance, respectively.

Beginning with the cumulative responses, we observe that the peripheral countries exhibit stronger responses in both the one- and three-year perspectives. There is a larger difference after the first four quarters than during the first twelve quarters, which is further evidence that the differences among responses are mostly short term.

For example, we note cumulative one-year responses of $1.3 \%$ and $1.1 \%$ in IR and ES, respectively. However, core countries like AT and DE show a close to zero response. Regarding the cumulative three-year response, we observe a similar pattern for the cumulative three-year response, although the difference between core and peripheral countries becomes smaller, as mentioned above. For the core countries, NL has the highest percent of explained variance. In the three-year perspective, $5 \%$ of house price movements can be explained by the monetary-easing shock. In contrast, the interest rate shock can explain a higher percentage of house price movements for the peripheral countries. Approximately $27 \%$ and $23 \%$ of the changes in house prices for IR and ES, respectively, are attributable to the monetary-easing shock.

\section{[Place Figure 4 about here]}

Obviously, the cumulative response and explained variance differ by country. While the housing markets in AT, BE, FI, FR, and DE remain stable after the shock, housing markets in IR and ES, where the mortgage markets tend to be more liberalized, show substantially higher responses. The channel works as follows: An increase in the gap from the Taylor rule rate may result in a decrease in perceived risk or an increase in risk tolerance, and therefore inject more liquidity into the system. Mortgage market liberalization allows for higher leverage, which increases the risk-taking capacities of households, financial institutions, and investors. It thus facilitates excessive risk-taking in the 
housing market. As a result, households, financial institutions, and investors may overreact to a one-time increase in house prices triggered by monetary policy easing.

On average, the responses in the peripheral countries are also more acute than in the core countries. Such differences could be due to differences in domestic demand. As Rubio and CarrascoGallego (2015a) show, domestic demand growth is extremely strong at the periphery but very weak at the core. In countries with stronger domestic demand, liberalized mortgage markets are more likely to facilitate excessive risk-taking behavior of investors or homeowners.

In order to fully visualize the influence of a deviation from the Taylor rule rate on respective house prices, we conduct a counterfactual analysis. We assume that, since joining the EMU (Italy, Ireland, Spain, and Portugal in January 1999 and Greece in January 2001), GIIPS countries have been under the same monetary policy stance as Germany. This implies that the ECB could either set the suitable target rate for these peripheral countries, or that GIIPS could completely converge with core area countries. We apply the deviation from the Taylor rule rate for Germany (as shown by the dotted line in Figure 5) to GIIPS countries as a counterfactual policy stance. The solid line shows the actual stance of GIIPS since joining the EMU, which has obviously been more accommodative than that of Germany.

\section{[Place Figure 5 about here]}

Figure 6 illustrates simulated house prices under the counterfactual monetary policy stance for GIIPS. All other contributors to house prices, including mortgage market institutional factors, credit supply, sentiment, current account balance, and the fundamental parts of house prices, are based on actual values. This means that the systemic differences between the simulated counterfactual price and the observed price are triggered purely by the differences between the two stances. As the fundamental value is set as the predicted value according to Equation (1), the depicted change in house prices is attributed entirely to the non-fundamental house price component. In Figure 6, simulated counterfactual prices are shown by the dashed line, simulated house prices using GIIPS actual policy stance are shown by the dashed-dotted line, and historical house prices over the 1993-2007 period are illustrated by the solid line.

Note that the predicted house price fits the observed price quite well. However, there is an obvious divergence between counterfactual and predicted house prices in Ireland and Spain. The divergence begins in 1999, and becomes increasingly distinct over time. By the second quarter of 2007 , it is obvious that house prices in Ireland and Spain would drop by $25 \%$ and $13 \%$, respectively, if both countries operated under the same policy stance as Germany.

\section{[Place Figure 6 about here]}

Next, we conduct another counterfactual analysis in order to explore whether adopting more restrictive mortgage market regulations in GIIPS countries would eliminate the adverse impact of common monetary policy on the housing market. We assume that, during the 2000s, GIIPS countries all featured more conservative mortgage markets, as in Germany. The counterfactual 
mortgage market for the five countries is then set as: a predominant share of fixed rate mortgages, a maximum LTV ratio of 0.8 , limited mortgage securitization, moderate government participation, and no possibility for mortgage equity withdrawals. In this simulation, the monetary policy stance, credit supply, sentiment, current account balance, and fundamental house price changes are based on the actual values for the five countries.

Figure 7 shows a simulation of counterfactual house prices (as shown by the dashed line), predicted house prices with actual mortgage market institutional factors (shown by the dasheddotted line), and observed house prices (shown by the solid line). As in Figure 6, the obvious divergence between simulated house prices using counterfactual mortgage market regulations and predicted house prices using actual mortgage market factors appears solely in Ireland and Spain, which experienced an unprecedented housing boom during the 2000s.

As shown in Figure 7, Irelands counterfactual price is $35 \%$ below the historical price, while Spains counterfactual price is $16 \%$ lower. Therefore, our results indicate that macro-prudential mortgage market regulation can be a reliable tool for controlling price movements. This is particularly important if there is no convergence of macroeconomic fundamentals (GDP) between the peripheral and core countries, because the ECB rate may not be appropriate for peripheral countries in that case.

\section{[Place Figure 7 about here]}

\section{Individual Mortgage Market Indicators}

In order to derive more detailed implications about how mortgage market structure affects non-fundamental house prices, we look more closely at the individual components of the mortgage market indicators and how they affect the transmission of an external interest rate shock.

We also forecast the responses to a 1-standard deviation monetary-easing shock from the first through the twentieth quarter after the shock. We compare the responses of more and less liberal mortgage markets based on individual indicators. In the liberal market (in red), $M_{i, t}$ is set at 0.75 for the corresponding indicator; in the less liberal market (in black), $M_{i, t}$ is set as 0.25 for the corresponding indicator.

We first examine mortgage rate type, and distinguish between variable and fixed rate. In a variable rate contract, the lending rate floats with, or is frequently adjusted to, a short-term market interest rate. In a fixed rate contract, the lending rate remains constant for the duration of the contract.

Figure 8 shows there is no significant difference in the response to monetary impulses in the two markets dominated by fixed and variable mortgage rates, both for the core and peripheral countries. Moreover, the variance decomposition, as shown in Table A5, model 4, indicates there is only a limited impact on the non-fundamental house price. Based on OECD countries, Calza et al. (2013) show that mortgage rate type yields a considerably stronger impact of the monetary impulse on home price, compared to LTV ratio and mortgage equity withdrawals. However, based on our 
analysis, variable mortgage rate is not the predominant factor in triggering the destabilization effects of monetary policy on the housing market for Euro area countries.

\section{[Place Figure 8 about here]}

Next, we analyze the effect of MEW. An important feature of mortgage market structure is whether households are able to withdraw equity due to an increase in value of their underlying real estate. Home equity withdrawals can be used to finance consumption and home investments. The literature shows a consistently close relationship between mortgage equity withdrawals and the boom and bust cycles of housing markets (Mian and Sufi (2011)).

As illustrated in Figure 9, in the core countries, we observe no statistically significant difference in the reaction to an interest rate shock between countries with more and less liberal mortgage markets. The variance decomposition (Table A5, model 5) illustrates that the impact of a monetary policy shock remains limited for the core countries. In contrast, Figure 9 also illustrates that, for the peripheral countries, an interest rate shock has a more severe impact (up to $0.7 \%$ in the second quarter after the shock) on the non-fundamental house price component when the potential for MEW exists. This effect remains close to zero in the more conservative market, however. The variance decomposition (Table A5, model 5) shows that the monetary policy shock can explain over $36.49 \%$ of the movement in non-fundamental house prices in peripheral countries with liberal mortgage markets.

\section{[Place Figure 9 about here]}

We also explore the relevance of the maximum LTV ratio in the mortgage market. LTV is relevant because an extended ratio implies more relaxed credit constraints on borrowers. Firsttime home buyers can especially benefit from high LTVs, because borrowers require less equity, which simplifies access to mortgage loans. This facilitates the transmission of a monetary policy shock via the balance sheet channel and the risk-taking channel.

Figure 10 shows that, in the core countries, non-fundamental house price shows a positive response in both markets. But the reverse of the interest rate shock impacts prices significantly more strongly in the market with a higher maximum LTV ratio in the second quarter after the shock. In the peripheral countries, there is a significantly higher response (up to a $0.2 \%$ increase in house prices) to the monetary policy shock in the countries with high LTV ratios until the fourth quarter after the shock. Table A5, model 6, shows that the explained forecasting error variance is $7.22 \%$ for the mortgage market with a higher maximum LTV ratio in the core countries, while it is $10.02 \%$ for the market with a higher LTV ratio in the peripheral countries. For countries with lower maximum LTV ratios, the explained variance remains small in both the core and peripheral countries.

Thus, we find that LTV plays a crucial role in determining a housing market, because it supports a boom in the non-fundamental house price component after an interest rate shock in both the core and peripheral countries. This finding is consistent with previous literature about the LTV ratio's 
relevance as a macro-prudential policy tool that can be used to adjust housing market stability. As Mendicino and Punzi (2014) show in a DSGE model, LTV ratios can be used to mitigate the procyclicality that can arise from the interlinkages on mortgage markets. Rubio and Carrasco-

Gallego (2015b) also use a DSGE model to show that LTV ratios can be used as a macro-prudential tool to improve financial stability.

\section{[Place Figure 10 about here]}

We also take a closer look at the role of mortgage securitization, which is designed to increase banks' liquidity and loan supply capacity (Altunbas et al. (2009)). However, due to the problems of moral hazard and adverse selection, it may reduce banks' incentives to screen and monitor their borrowers during a period of booming housing markets. Consequently, mortgage securitization may lead to deregulation of the mortgage market, and ultimately support overheating of housing markets (Allen and Carletti (2006); Duffee and Zhou (2001); Gorton and Pennacchi (1995)). Shin (2009) and Rajan (2005) note that the larger risk-taking capacity of the shadow banking system leads to increased demand for new assets in order to fill the expanding balance sheets and leverage. This results in securitization becoming increasingly important for financial stability.

As illustrated in Figure 11, and differing from studies based on OECD countries, we observe insignificant difference in the reaction to a monetary policy shock based on MS for the European countries. The explained variance of the non-fundamental house price remains small in all cases (Table A5, model 7). The reason for this may be that most EMU countries do not allow for mortgage securitization, or only for limited securitization, and banks in the EMU still rely primarily on deposits to guarantee mortgages.

\section{[Place Figure 11 about here]}

For the last mortgage market indicator, we focus on government participation (GP), which includes subsidies to selected groups like first-time and low-income buyers, who influence the demand side of the housing market. The GP index also reflects subsidies to buyers through savings account contributions, as well as the tax deductibility of housing expenses. Thus, it describes the extent to which the government supports affordable income, promotes homeownership, and encourages home purchases for lower-income households.

At the core (Figure 12), we note a significantly lower impact of monetary policy in the second and fourth quarters after the shock for more liberal countries. The interest rate shock can explain $8.38 \%$ of the forecasting error variance in core countries with high GP (Table A5, model 8). For the peripheral countries, we observe a significantly higher response in the third quarter after the shock in the more liberal countries. The explained variance of the non-fundamental house price, as shown in Table A5, model 8, is $6.96 \%$ for the peripheral countries with high GP. Policies such as tax deductions may lead to overreactions of homeowners to the housing market in both core and peripheral countries. 


\section{[Place Figure 12 about here]}

\section{E. Additional Results and Robustness Checks}

Because deviations from the Taylor rule and non-fundamental house prices are not observable, we first need to estimate the two variables. We note that the misspecification in the fundamental equation will carry over into the generated residual. Therefore, we conduct two types of robustness checks: 1) using alternative methods to define price runups and monetary policy stances, and 2) using observed values to measure non-fundamental price runups.

\section{E.1. Alternative Estimators for Fundamental Values}

We include the dynamics in the fundamental equation by adding a lagged dependent variable into Equation (3), as follows:

$$
\begin{aligned}
\Delta \ln P_{i, t}= & \alpha_{i}+\eta \Delta \ln P_{i, t-1}+\sum_{p=1}^{4} \beta_{1 i, p} \Delta \ln G D P_{i, t-p}+\sum_{p=1}^{4} \beta_{2 i, p} \Delta \ln C P I_{i, t-p} \\
& +\sum_{p=1}^{4} \beta_{3 i, p} \Delta \ln P O P_{i, t-p}+\sum_{p=1}^{4} \beta_{4 i, p} \Delta \operatorname{lnIncome~}_{i, t-p}+\sum_{p=1}^{4} \beta_{5 i, p} \Delta U E_{i, t-p} \\
& +\sum_{p=1}^{4} \beta_{6 i, p} \Delta \ln \text { Permit }_{i, t-p}+\sum_{p=1}^{4} \beta_{7 i, p} \Delta M r_{i, t-p}+e_{i, t}^{h p}
\end{aligned}
$$

The long-term effect of fundamental factors on house prices can be calculated as:

$$
\begin{aligned}
\Delta \ln P_{i, t}= & \frac{1}{1-\eta} \alpha_{i}+\frac{1}{1-\eta} \sum_{p=1}^{4} \beta_{1 i, p} \Delta \ln G D P_{i, t-p}+\frac{1}{1-\eta} \sum_{p=1}^{4} \beta_{2 i, p} \Delta \ln C P I_{i, t-p} \\
& +\frac{1}{1-\eta} \sum_{p=1}^{4} \beta_{3 i, p} \Delta \ln P O P_{i, t-p}+\frac{1}{1-\eta} \sum_{p=1}^{4} \beta_{4 i, p} \Delta \text { lnIncome }_{i, t-p} \\
& +\frac{1}{1-\eta} \sum_{p=1}^{4} \beta_{5 i, p} \Delta U E_{i, t-p}+\frac{1}{1-\eta} \sum_{p=1}^{4} \beta_{6 i, p} \Delta \ln \text { Permit }_{i, t-p} \\
& +\frac{1}{1-\eta} \sum_{p=1}^{4} \beta_{7 i, p} \Delta M r_{i, t-p}+\epsilon_{i, t}^{h p}
\end{aligned}
$$

Thus, non-fundamental house price runups can be measured as deviations from long-term changes in fundamental values $\left(\varepsilon_{i, t}^{h p}\right)$. As shown in Figure 13, the impulse response remains robust. Peripheral countries with more developed mortgage markets respond significantly more strongly than other countries. As shown in Table A6, model 9, the monetary shock can explain over $24 \%$ of the variation in non-fundamental house price runups in peripheral countries that have more liberal mortgage markets. 


\section{[Place Figure 13 about here]}

Koetter and Poghosyan (2010) and Kholodilin et al. (2007) define the non-fundamental house price as a deviation from the equilibrium trend price. Based on this definition, we can rewrite Equation (3) as:

$$
\begin{aligned}
\ln P_{i, t}= & \alpha_{i}+\beta_{1 i} \ln G D P_{i, t-p}+\beta_{2 i} \ln C P I_{i, t-p}+\beta_{3 i} \ln P O P_{i, t-p} \\
& +\beta_{4 i} \ln \operatorname{Income}_{i, t-p}+\beta_{5 i} U E_{i, t-p}+\beta_{6 i} \ln \operatorname{Permit}_{i, t-p} \\
& +\beta_{7 i} M r_{i, t-p}+e_{i, t}^{h p}
\end{aligned}
$$

Further, considering the non-stationarity of the series, we use a Dynamic Ordinary Least Squares Estimator (DOLS) (Stock and Watson (1993)) to solve Equation (8). Unlike Koetter and Poghosyan (2010) and Kholodilin et al. (2007), we do not estimate Equation (8) in a panel setting. This is because we do not wish to impose any restrictions on the long-term relationship between house prices and fundamental variables to force them to remain constant across countries. The estimated residuals are defined as the non-fundamental house price values.

As shown in Figure 14, the response in peripheral countries with more liberal mortgage markets is even stronger than in the baseline model. Our conclusion thus remains unchanged: More conservative mortgage market regulations can help offset the adverse impact of deviations from the Taylor rule rate on housing market stability. The results in Table A6, model 10, show that monetary-easing shocks can explain over $15 \%$ of the variation of non-fundamental house price runups for peripheral countries with liberal mortgage markets. However, for countries with more restrictive mortgage markets, monetary-easing shocks play a less important role.

\section{[Place Figure 14 about here]}

We also use a more straightforward method to measure house price runups: the price-to-rent ratio. Rent data for the eleven countries comes from the OECD database. The advantage of using the price-to-rent ratio is that it captures observed data. The disadvantage, however, is that it may ignore some other pertinent drivers of fundamental price changes such as population change, income growth, and supply restrictions.

As shown in Figure 15, the results based on the price-to-rent ratio are qualitatively robust. For peripheral countries with liberal mortgage market developments, a 1-standard deviation monetaryeasing shock can result in an up to $7 \%$ increase in the price-to-rent ratio. In contrast, the response for core countries is negligible.

\section{[Place Figure 15 about here]}

\section{E.2. Alternative Estimators for the Taylor Rule Rate}

Instead of the traditional Taylor rule rate, as shown in Equation (4), Gerlach-Kristen (2003) suggests adding interest rate smoothing to the TR estimation. This means that the TR estimates 
not only relate to current inflation levels and the output gap, but also to the lagged short-term rate. Hence, we can modify the traditional TR rate as:

$$
r_{i, t}=\left(1-\gamma_{3, i}\right)\left[\gamma_{0, i}+\gamma_{1, i}\left(\pi_{i, t}-\pi_{i, t}^{*}\right)+\gamma_{2, i}\left(y_{i, t}-y_{i, t}^{*}\right)\right]+\gamma_{3, i} r_{t-1}+e_{i, t}^{T R}
$$

where $\gamma_{3, i}$ is the coefficient for the smoothing term. Empirically, Equation (9) is estimated as:

$$
r_{i, t}=\tilde{\gamma}_{0, i}+\tilde{\gamma}_{1, i}\left(\pi_{i, t}-\pi_{i}^{*}\right)+\tilde{\gamma}_{2, i}\left(y_{i, t}-y_{i, t}^{*}\right)+\tilde{\gamma}_{3, i} r_{t-1}+e_{i, t}^{T R}
$$

using a GMM estimator with up to four lags of $\pi_{i, t}, y_{i, t}$ as the instrument variables. Equation (9) can be converted to Equation (10) with the relationships as follows: $\gamma_{0, i}=\tilde{\gamma}_{0, i} /\left(1-\tilde{\gamma}_{3, i}\right)$,

$\gamma_{1, i}=\tilde{\gamma}_{1, i} /\left(1-\tilde{\gamma}_{3, i}\right)$ and $\gamma_{2, i}=\tilde{\gamma}_{2, i} /\left(1-\tilde{\gamma}_{3, i}\right)$. As illustrated in Figure 16, the response of the nonfundamental house price to monetary policy shock is very similar to the baseline model. Taylor (2007) also shows that using smoothed Taylor rule rate generated similar results as the unsmoothed rates.

\section{[Place Figure 16 about here]}

\section{E.3. Further Results and Other Robustness Checks}

Account Balance In addition to interest rate stance and housing credit, Sá et al. (2014), Diamond and Rajan (2005), Fratzscher et al. (2010), and Ferrero (2012) show that account balance may affect housing cycles. A negative account balance shock can be interpreted as an unexpected increase in foreign demand for domestic assets. Such an increase could lead to booms in domestic asset prices. The negative relationship with current account balance can be explained by Bernanke's global savings glut hypothesis (Bernanke (2005)). The literature also suggests that housing booms are largely tied to investor sentiment. For example, Case and Shiller (1988) and Ling et al. (2015) show that sentiment can affect homebuyers' investment decisions. Therefore, we add the two variables account balance and consumer sentiment to the panel VAR model.

Consistent with Sá et al. (2014), we find that mortgage market development can amplify the response to capital inflow shocks, but only in the peripheral countries. As shown in Figure A3, capital inflow exhibits no significant influence in the core countries, and we also observe no difference between more and less liberal mortgage market structures. In the peripheral countries, however, there is a significant impact on house prices between the second and fourth quarters after the interest rate shock, with the liberal markets showing a more pronounced $0.2 \%$ increase in nonfundamental house prices. For sentiment, we find virtually no impact on the response to a negative interest rate shock.

Constant Maximum Loan-to-Value Ratio As the de facto measure of leverage in the housing market, the maximum LTV ratio may suffer from endogeneity, because households and financial institutions may respond to monetary easing by increasing leverage. Most Euro countries did not 
really restrict maximum LTV before 2012, so we use the constant maximum LTV ratio (before 2000) in our robustness test. As shown in Table A6, model 13, the forecasting error variance of the non-fundamental house price by a monetary policy shock in countries with a deregulated mortgage market tends to drop. However, it is still significantly higher when compared to countries with a regulated mortgage market, where the impact of monetary policy remains marginal.

Exogenous Monetary Policy Shock We note that any endogeneity between the interest rate shock and credit supply shock poses a further concern. We follow the approach in den Haan et al. (2007) and Milcheva (2013), and compare the effect on non-fundamental house price changes stemming from a monetary policy shock with the effect on non-fundamental house price changes stemming from a credit supply shock (when the value of the credit supply is set equal to the value observed during the "monetary easing", and the values for the remaining variables are then obtained by iterating on the VAR). The former is the effect of monetary policy shock on the house prices; the latter measures the responses to a monetary policy-induced credit supply shock. The difference between the impulse response functions of the two types of shocks is equal to the response to a monetary policy shock when the response of the credit-to-GDP ratio is restricted to zero in every period. This can be interpreted as the response of house prices to an exogenous monetary policy shock when credit supply is held constant. As shown in Table A6, model 14, the explained variance by an interest rate shock in the mortgage market with high LTV and MS ratios drops only slightly by $2 \%$ at $T=20$.

\section{Conclusion}

This paper provides empirical evidence of how monetary policy and mortgage market regulation impact housing markets using a sample of eleven Euro area countries. To identify the relationships among non-fundamental house prices, monetary policy stance, and mortgage market structure, we use a three-stage estimation approach. First, we estimate non-fundamental runups as the deviations of observed house price changes from the respective fundamental price changes. Second, we implement the Taylor rule concept in order to proxy for monetary policy stance. In our third and final stage, we analyze the impact of monetary policy on non-fundamental house prices using an interacted panel VAR setting, conditional on the mortgage market development in each country.

Our empirical evidence suggests that a negative shock to deviations from the Taylor rule rate can significantly trigger boom and bust cycles in housing markets by impacting non-fundamental house prices in the Euro area. A shock to the monetary policy stance can explain over $20 \%$ of the forecasting error variance of non-fundamental house price runups in Spain and Ireland. The counterfactual analysis implies that house prices in Ireland and Spain would be 25\% and $13 \%$ lower, respectively, if the ECB rate for the two countries led to the same stance as in Germany. Furthermore, monetary policy shocks are not generally transmitted equally among countries. We note that country-specific mortgage market conditions are key to determining how external shocks 
transmit to the respective housing market. Those with more liberal mortgage markets, as represented by variable mortgage rates, availability of mortgage equity withdrawals, high loan-to-value ratios, high degrees of mortgage securitization, and high degrees of government participation, are more vulnerable to the external shocks that can result from interest rate movements. Based on the results of a counterfactual analysis where it is assumed that the mortgage markets in Spain and Ireland were as conservative as in Germany, the house prices in Spain and Ireland would be 16\% and $35 \%$ lower, respectively, irrespective of a too loose monetary policy.

Our findings offer important implications for macro-prudential policy and for the design of mortgage markets in a monetary union where monetary policy is too loose for some countries while too restrictive for others. As monetary policy can have adverse side effects and even destabilize housing markets, regulations on housing finance are a vital tool for central banks to use in an effort to close this gap. Countries with a high maximum LTV ratio and a high degree of government participation may need to closely monitor the housing market during times of more relaxed monetary policies, because the side effects of an accommodative monetary policy may be amplified. For peripheral countries, policymakers should also keep a close eye on the markets that allow for mortgage equity withdrawals.

On the other hand, policymakers may consider macro-prudential policies useful in preventing adverse housing bubbles triggered by monetary easing or interest rate gaps. Further studies could extend our work by proving the causality between monetary policy and housing market stability, as well as the causal relationship between deregulation in the banking system and housing market stability. 


\section{REFERENCES}

Adams, Z., and R. Füss, 2010, Macroeconomic determinants of international housing markets, Journal of Housing Economics 19, 38-50.

Adrian, T., P. Colla, and H. S. Shin, 2012, Which financial frictions? parsing the evidence from the financial crisis of 2007-2009., NBER Macoeconomics Annual 2012 27.

Adrian, T., and H.S. Shin, 2008, Financial intermediaries, financial stability, and monetary policy, Federal Reserve Bank of New York Staff Reports .

Ahearne, A. G., J. Ammer, B. M. Doyle, L. S. Kole, and R. F. Martin, 2008, House prices and monetary policy: A cross-country study, International Finance Discussion Papers. The Federal Reserve Board. .

Allen, F., and E. Carletti, 2006, Credit risk transfer and contagion, Journal of Monetary Economics $53,89-111$.

Allen, F., and K. Rogoff, 2011, Asset Prices, Financial Stability and Monetary Policy, The Riksbanks inquiry into the risks in the Swedish housing market (Sveriges Riksbank).

Altunbas, Y., L. Gambacorta, and D. Marques-Ibanez, 2009, Securitisation and the bank lending channel, European Economic Review 53, 996-1009.

Annett, A., 2006, House prices and monetary policy in the euro area, IMF Report .

Antipa, P., and R. Lecat, 2009, The housing bubble and financial factors: Insights from a structural model of the french and spanish residential markts., Banque de France Working Paper .

Aoki, K., J. Proudman, and G. Vlieghe, 2004, House prices, consumption, and monetary policy: a financial accelerator approach, Journal of Financial Intermediation 13, 414-435.

Barigozzi, M., A. M. Conti, and M. Luciani, 2014, Do euro area countries respond asymmetrically to the common monetary policy?, Oxford Bulletin of Economics and Statistics 76, 693-714.

Bauer, G. H., 2014, International house price cycles, monetary policy and risk premiums, Bank of Canada Working Paper. 
Bernanke, B., 2010, Monetary policy and the housing bubble, Speech at the Annual Meeting of the American Economic Association, Atlanta .

Bernanke, B. S., 2005, The global saving glut and the u.s. current account deficit, Remarks at The Homer Jones Lecture. St. Louis. MO .

Bernanke, B. S., and A. S. Blinder, 1992, The federal-funds rate and the channels of monetary transmission, American Economic Review 82, 901-921.

Bjoerksten, N., and M. Syrjaenen, 2000, How problematic are internal euro area differences?, European University Institute Working Paper .

Bruno, V., and H. S. Shin, 2014, Globalization of corporate risk taking, Journal of International Business Studies 45, 800-820.

Calza, A., T. Monacelli, and L. Stracca, 2013, Housing finance and monetary policy, Journal of the European Economic Association 11, 101-122.

Case, B., and R. J. Shiller, 1988, The behavior of home buyers in boom and post-boom markets., New England Economic Review 44.

Case, K. E., and R. J. Shiller, 2003, Is there a bubble in the housing market?, Brookings Papers on Economic Activity 299-362.

den Haan, W. J., S. W. Sumner, and G. M. Yamashiro, 2007, Bank loan portfolios and the monetary transmission mechanism, Journal of Monetary Economics 54, 904-924.

Diamond, D. W., and R. G. Rajan, 2005, Liquidity shortages and banking crises, Journal of Finance $60,615-647$.

Dipasquale, D., and W. C. Wheaton, 1994, Housing-market dynamics and the future of housing prices, Journal of Urban Economics 35, 1-27.

Disyatat, P., 2011, The bank lending channel revisited, Journal of Money Credit and Banking 43, $711-734$.

Dokko, J., B. M. Doyle, M. T. Kiley, J. Kim, S. Sherlund, J. Sim, and S. Van Den Heuvel, 2011, Monetary policy and the global housing bubble, Economic Policy 66, 233-283. 
Duffee, G. R., and C. S. Zhou, 2001, Credit derivatives in banking: Useful tools for managing risk?, Journal of Monetary Economics 48, 25-54.

Escobari, D., D. Damianov, and A. Bello, 2013, A time series test to identify housing bubbles, MPRA Paper .

Ferrero, A., 2012, House price booms, current accout deficits and low interest rates, Federal Reserve Bank of New York Staff Reports .

Fratzscher, M., L. Juvenal, and L. Sarno, 2010, Asset prices, exchange rates and the current account, European Economic Review 54, 643-658.

Gallin, J, 2006, The long-run relationship between house prices and income: Evidence fromlocal housing markets, Real Estate Economics 34, 417-438.

Gerlach, S., and G. Schnabel, 2000, The taylor rule and interest rates in the emu area, Economics Letters 67, 165-171.

Gerlach-Kristen, P., 2003, Interest rate reaction functions and the taylor rule in the euro area, $E C B$ Working paper .

Giuliodori, M., 2004, Nominal shocks and the current account: A structural var analysis of 14 oecd countries, Review of World Economics 140, 569-591.

Goodman, A. C., and T. G. Thibodeau, 2008, Where are the speculative bubbles in u.s. housing markets?, Journal of Housing Economics 17, 117-137.

Gorton, G. B., and G. G. Pennacchi, 1995, Banks and loan sales - marketing nonmarketable assets, Journal of Monetary Economics 35, 389-411.

Greiber, C., and R. Setzer, 2007, Money and housing - evidence for th eeuro area and the us., Deutsche Bundesbank Discussion Paper Series .

Hoffmann, A., and T. Nitschka, 2008, Securitization of mortgage debt, asset prices and international risk sharing, Oxford Review of Economic Policy 24, 180-205.

Hott, C., 2014, Fundamental and non-fundamental explanations for house price fluctuations, Oesterreichische Nationalbank: Proceedings of OeNB Workshops No. 19 . 
Hott, C., and T. Jokipii, 2012, Housing bubbles and interest rates, Swiss National Bank Working Papers .

Iacoviello, M., 2005, House prices, borrowing constraints, and monetary policy in the business cycle, American Economic Review 95, 739-764.

Iacoviello, M., and R. Minetti, 2003, Financial liberalization and the sensitivity of house prices to monetary policy: Theory and evidence, Manchester School 71, 20-34.

Iacoviello, M., and S. Neri, 2010, Housing market spillovers: Evidence from an estimated dsge model, American Economic Journal-Macroeconomics 2, 125-164.

IMF, 2008, The changing housing cycle and the implications for monetary policy, IMF Report .

IMF, 2011, Global financial stability report durable financial stability, IMF Report .

Jarocinski, M., and F. Smets, 2008, House prices and the stance of monetary policy, Federal Reserve Bank of St. Louis Review .

Kaefer, B., 2014, The taylor rule and financial stability: A literature review with application for the eurozone, Joint Discussion Paper Series in Economics by the Universities of Aachen, Gießen, Göttingen, Kassel, Marburg and Siegen, No. 30-2014 .

Kholodilin, K. A., J. Menz, and B. Siliverstovs, 2007, What drives housing prices down? evidence from an international panel, DIW discussion paper .

Koetter, M., and T. Poghosyan, 2010, Real estate prices and bank stability, Journal of Banking $\mathcal{E}$ Finance 34, 1129-1138.

Ling, D. C., J. T. L. Ooi, and T. T. T. Le, 2015, Explaining house price dynamics: Isolating the role of nonfundamentals, Journal of Money Credit and Banking 47, 87-125.

Maclennan, D., J. Muellbauer, and M. Stephens, 1998, Asymmetries in housing and financial market institutions and EMU, Oxford Review of Economic Policy 14, 54-80.

Mendicino, C., and M. T. Punzi, 2014, House prices, capital inflows and macroprudential policy, Journal of Banking \& Finance 49, 337-355. 
Mian, A., and A. Sufi, 2011, House prices, home equity-based borrowing, and the us household leverage crisis, American Economic Review 101, 2132-2156.

Milcheva, S., 2013, A bank lending channel or a credit supply shock?, Journal of Macroeconomics $37,314-332$.

Milcheva, S., and B. Zhu, 2015, Bank integration and co-movements across housing markets, Journal of Banking $\&$ Finance forthcoming.

Muellbauer, J., and A. Murphy, 1997, Booms and busts in the uk housing market, Economic Journal 107, 1701-1727.

Muellbauer, J., and A. Murphy, 2008, Housing markets and the economy: the assessment, Oxford Review of Economic Policy 24, 1-33.

Nechio, F., 2011, Monetary policy when one size does not fit all, Federal Reserve Bank of San Francisco Economic Letter .

Rajan, R., 2005, Has financial development made the world riskier?, NBER Working paper .

Reinhart, C. M., and V. Reinhart, 2008, Capital flow bonanzas: An encompassing view of the past and present, CEPR Discussion Paper.

Reinhart, C. M., and K. Rogoff, 2008, Is the 2007 u.s. subprime financial crisis so different? an international historical comparison, American Economic Review 98.

Rubio, M., 2014, Housing-market heterogeneity in a monetary union, Journal of International Money and Finance 40, 163-184.

Rubio, M., and J. A. Carrasco-Gallego, 2015a, Liquidity, interest rates and house prices in the euro area: A dsge analysis., Journal of European Real Estate Research Forthcoming.

Rubio, M., and J. A. Carrasco-Gallego, 2015b, Macroprudential and monetary policy rules: A welfare analysis, Manchester School 83, 127-152.

Sá, F., P. Towbin, and T. Wieladek, 2014, Capital inflows, financial structure and housing booms, Journal of the European Economic Association 12, 522-546. 
Scantee, R., and O. Stoica, 2013, Evaluation of the european central bank's monetary policy in terms of taylor rule, Accounting and Finance Research 2, 104-109.

Seyfried, B. K., 2010, Monetary policy and housing bubbles: A multinational perspective, Research in Business and Economics Journal .

Shin, H. S., 2009, Securitisation and financial stability, Economic Journal 119, 309-332.

Simo-Kengne, B. D., M. Balcilar, R. Gupta, M. Reid, and G. C. Aye, 2013, Is the relationship between monetary policy and house prices asymmetric across bull and bear markets in south africa? evidence from a markov-switching vector autoregressive model, Economic Modelling 32, $161-171$.

Stock, J. H., and M. W. Watson, 1993, A simple estimator of cointegrating vectors in higher-order integrated systems, Econometrica 61, 783-820.

Svensson, L. E. O., 1999, Inflation targeting: Some extensions, Scandinavian Journal of Economics $101,337-361$.

Taylor, J. B., 1993, Discretion versus policy rules in practice, Camegie-Rochester Conference Series on Public Policy 39.

Taylor, J. B., 2007, Housing and monetary policy, Stanford Institute for Economic Policy Research Discussion Paper .

Tsatsaronis, K, and H. Zhu, 2004, What drives house price dynamics: Cross-country evidence, BIS Quarterly Review . 


\section{Appendix A. Data sources and Definitions}

Table A1: Data sources and Definitions

\begin{tabular}{|c|c|c|}
\hline Variables & Sources & Description \\
\hline Real house prices & BIS & $\begin{array}{l}\text { House price indices are collected from BIS and are based on } \\
\text { national sources. BIS data was not available for Greece or } \\
\text { Portugal, so we use data from Oxford Economics. }\end{array}$ \\
\hline Real GDP & OECD & \\
\hline $\begin{array}{l}\text { Households Credit-to- } \\
\text { GDP ratio }\end{array}$ & BIS & $\begin{array}{l}\text { Credit from domestic banks to households as a share of GDP. } \\
\text { Data for Austria begins with 4Q1995. Data for Greece begins } \\
\text { with 4Q1994. Data for Ireland begins with 1Q2002. We in- } \\
\text { terpolate missing data by using credit from domestic banks to } \\
\text { non-financial private sectors. }\end{array}$ \\
\hline Inflation & OECD & CPI inflation rate. \\
\hline Population & Oxford Economics & Total population. \\
\hline $\begin{array}{l}\text { Population between } 20 \\
\text { and } 44 \text { years old }\end{array}$ & World bank & In percent of total population. \\
\hline Short-term interest rate & OECD & \\
\hline Unemployment rate & OECD & \\
\hline Consumer sentiment & OECD & \\
\hline Mortgage rate & $\begin{array}{l}\mathrm{ECB}, \mathrm{OECD} \text { and na- } \\
\text { tional sources. }\end{array}$ & $\begin{array}{l}\text { From } 2003 \text { to } 2012 \text {, we use household borrowing costs for pur- } \\
\text { chasing a new home from the European Central Bank (ECB). } \\
\text { In order to interpolate the above data back to } 1990 \text {, however, } \\
\text { we use the mortgage rate collected from the national statisti- } \\
\text { cal offices of the above countries. For the remaining countries, } \\
\text { we also use the mortgage rate available from their national } \\
\text { sources. In the case of missing mortgage rate data, we use the } \\
\text { ten-year government bond yield in countries that have mixed- } \\
\text { rate mortgages as the predominant mortgage contracts. For } \\
\text { countries that use a variable mortgage rate more widely, we } \\
\text { choose the one-year government bond yield instead. }\end{array}$ \\
\hline Building permits & $\begin{array}{l}\text { OECD, Eurostat, Ox- } \\
\text { ford Economics, and na- } \\
\text { tional sources. }\end{array}$ & $\begin{array}{l}\text { Volume index. Data for Belgium, Finland, Germany, and } \\
\text { Spain come from national sources. Data for Austria, France, } \\
\text { and Ireland come from OECD. We also use Eurostat building } \\
\text { permit index data to interpolate when OECD housing permit } \\
\text { volume data is incomplete. For Greece, the Netherlands, and } \\
\text { Italy, housing permit data is not available, so we use housing } \\
\text { starts instead. Housing start data come from Oxford Eco- } \\
\text { nomics. }\end{array}$ \\
\hline Account balance & OECD & Countries current account balance, in percent of GDP. \\
\hline Financial leverage & U.S. Flow of Funds & $\begin{array}{l}\text { The sum of the equity and total liabilities of U.S. broker- } \\
\text { dealers divided by their equity. }\end{array}$ \\
\hline Oil prices & OECD & Price of crude oil. \\
\hline $\begin{array}{l}\text { ECU-Euro to U.S. dollar } \\
\text { rate }\end{array}$ & OECD & \\
\hline Mortgage rate type & Literature & $\begin{array}{l}\text { Before 2003: Tsatsaronis and Zhu }(2004) ; \text { Maclennan et al. } \\
\text { (1998); between } 2003 \text { and 2012: } \operatorname{IMF}(2011) \text {. }\end{array}$ \\
\hline $\begin{array}{l}\text { Mortgage equity with- } \\
\text { drawal }\end{array}$ & Literature & $\begin{array}{l}\text { Before 2003: Tsatsaronis and Zhu (2004); Maclennan et al. } \\
\text { (1998); between } 2003 \text { and 2005: IMF (2008); between } 2006 \text { to } \\
\text { 2012: IMF (2011). }\end{array}$ \\
\hline $\begin{array}{l}\text { Maximum loan to value } \\
\text { ratio }\end{array}$ & Literature & $\begin{array}{l}\text { Before 2003: Tsatsaronis and Zhu }(2004) ; \text { Maclennan et al. } \\
\text { (1998); between } 2003 \text { and 2012: } \operatorname{IMF}(2011) \text {. }\end{array}$ \\
\hline Mortgage securitization & Literature & Hottmann and Nitschka (2008). \\
\hline $\begin{array}{l}\text { Government participa- } \\
\text { tion }\end{array}$ & Literature & IMF 2011); Maclennan et al. (1998. \\
\hline
\end{tabular}




\section{Appendix B. Mortgage Market Indicators}

Table A2: Mortgage Market Indicators

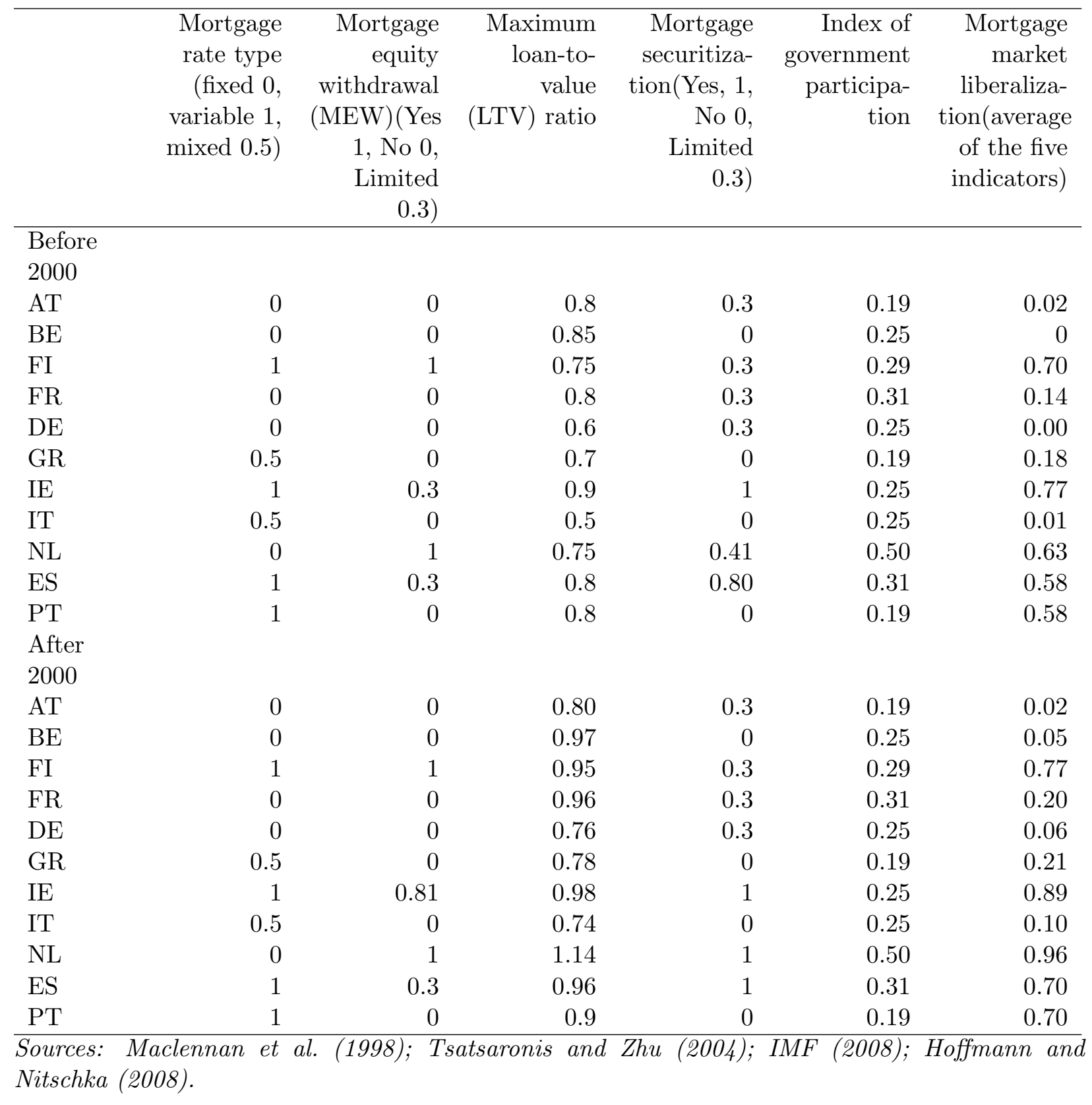




\section{Appendix C. F-Test and $R^{2}$ for House Price Fundamental Values}

Table A3: F-Test and $R^{2}$ for House Price Fundamental Values

\begin{tabular}{|c|c|c|c|c|c|c|c|c|}
\hline Country & Pop. & Permit & Income & GDP & Unemp. Rate & CPI & Mortgage Rate & $R^{2}$ \\
\hline \multirow{2}{*}{$\mathbf{A T}$} & 17.902 & -4.391 & -7.506 & -10.473 & 0.173 & -0.127 & 2.195 & \multirow{2}{*}{0.266} \\
\hline & (1.007) & $(0.793)$ & $(1.204)$ & $(0.902)$ & (1.127) & $(1.771)$ & $(0.870)$ & \\
\hline \multirow{2}{*}{$\mathrm{BE}$} & 0.475 & $-4.722^{*}$ & -5.275 & 16.184 & 0.240 & -9.775 & -0.522 & \multirow{2}{*}{0.282} \\
\hline & $(1.531)$ & $(2.455)$ & $(0.784)$ & $(1.509)$ & $(0.890)$ & (1.103) & $(1.380)$ & \\
\hline \multirow{2}{*}{ FI } & 2.447 & -16.819 & -16.948 & 45.553 & $-1.165^{* *}$ & $-37.543^{* *}$ & -0.545 & \multirow{2}{*}{0.686} \\
\hline & $(0.977)$ & $(4.821)$ & $(2.047)$ & $(1.133)$ & $(3.017)$ & $(2.761)$ & $(4.170)$ & \\
\hline \multirow{2}{*}{ FR } & $4.383^{* * *}$ & 29.350 & 28.597 & 8.001 & $0.222^{* *}$ & -6.396 & $-0.239 * *$ & \multirow{2}{*}{0.843} \\
\hline & $(34.967)$ & $(1.329)$ & $(0.832)$ & $(6.097)$ & $(3.657)$ & $(1.538)$ & $(2.670)$ & \\
\hline \multirow{2}{*}{ DE } & 6.892 & 0.006 & -1.406 & $3.079^{*}$ & 0.682 & -10.064 & 0.207 & \multirow{2}{*}{0.314} \\
\hline & $(1.987)$ & $(1.528)$ & $(1.478)$ & $(2.380)$ & $(0.696)$ & $(4.687)$ & $(1.645)$ & \\
\hline \multirow{2}{*}{ GR } & $18.600^{* *}$ & $4.872^{*}$ & 4.610 & -19.610 & -0.076 & 11.752 & -0.905 & \multirow{2}{*}{0.688} \\
\hline & $(3.468)$ & $(2.108)$ & $(0.613)$ & $(0.592)$ & $(1.723)$ & $(1.822)$ & (1.018) & \\
\hline \multirow{2}{*}{ IE } & 5.147 & $7.053^{*}$ & 8.230 & -2.677 & -0.842 & -2.361 & 1.178 & \multirow{2}{*}{0.697} \\
\hline & $(5.504)$ & $(2.203)$ & $(1.342)$ & $(2.040)$ & $(1.370)$ & $(1.392)$ & $(1.973)$ & \\
\hline \multirow{2}{*}{ IT } & 2.950 & $-0.212^{* *}$ & $0.661^{* * *}$ & $-2.414^{*}$ & $1.115^{* *}$ & $3.409^{* *}$ & 0.206 & \multirow{2}{*}{0.771} \\
\hline & $(4.133)$ & $(3.511)$ & $(9.629)$ & $(2.261)$ & $(3.349)$ & $(3.229)$ & (1.397) & \\
\hline \multirow{2}{*}{ NL } & $-10.276^{* * *}$ & 25.347 & $26.562^{*}$ & $10.571^{* * *}$ & $-0.362^{* *}$ & $15.229^{* *}$ & 1.203 & \multirow{2}{*}{0.779} \\
\hline & $(10.483)$ & $(1.596)$ & $(2.151)$ & $(16.376)$ & $(3.148)$ & $(3.029)$ & $(4.028)$ & \\
\hline \multirow{2}{*}{ ES } & $7.915^{* * *}$ & 0.118 & 0.377 & 8.140 & 0.048 & -7.282 & $-0.255^{* *}$ & \multirow{2}{*}{0.855} \\
\hline & $(26.471)$ & $(5.457)$ & (6.015) & $(0.350)$ & $(0.336)$ & $(1.136)$ & $(3.107)$ & \\
\hline \multirow{2}{*}{ PT } & 13.502 & 1.163 & 1.229 & $4.829^{*}$ & $0.110^{* *}$ & -13.954 & -0.459 & \multirow{2}{*}{0.614} \\
\hline & (5.941) & (1.648) & (2.049) & $(2.118)$ & $(2.650)$ & (1.308) & $(1.332)$ & \\
\hline
\end{tabular}

Notes: Estimation for the period 1Q1992 to 4Q2012. The dependent variable is the quarterly log difference of house prices. Equation (3) is estimated using OLS. Cumulative effect is reported, which is calculated as the sum of the coefficients of the lagged predictors. F test statistics is reported in parenthesis. It tests the redundancy of each predictor (four lags) in Equation (3) for each country. $R^{2}$ is the determinant of coefficients for each country. ***, **, and * denote significance at the $1 \%, 5 \%$, and $10 \%$ levels, respectively. 


\section{Appendix D. Coefficients for TR}

Table A4: Coefficients for TR

\begin{tabular}{cllll}
\hline Country & $\gamma_{0}$ & $\gamma_{1}$ & $\gamma_{2}$ & $R^{2}$ \\
\hline \multirow{2}{*}{$\mathbf{A T}$} & $3.49^{* * *}$ & $1.58^{* * *}$ & 0.27 & 0.39 \\
& $(0.22)$ & $(0.28)$ & $(0.24)$ & \\
$\mathbf{B E}$ & $4.38^{* * *}$ & $1.47^{* * *}$ & -0.01 & 0.54 \\
& $(0.25)$ & $(0.12)$ & $(0.27)$ & \\
FI & $4.40^{* * *}$ & $2.64^{* * *}$ & $-0.89^{* * *}$ & 0.59 \\
& $(0.26)$ & $(0.22)$ & $(0.16)$ & \\
FR & $4.69^{* * *}$ & $1.18^{* * *}$ & $0.43^{*}$ & 0.67 \\
& $(0.22)$ & $(0.07)$ & $(0.23)$ & \\
DE & $4.28^{* * *}$ & $1.50^{* * *}$ & 0.11 & 0.61 \\
& $(0.15)$ & $(0.12)$ & $(0.12)$ & \\
GR & $2.73^{* * *}$ & $1.89^{* * *}$ & 0.17 & 0.63 \\
& $(0.49)$ & $(0.16)$ & $(0.21)$ & \\
IE & $5.12^{* * *}$ & $0.89^{* * *}$ & -0.04 & 0.21 \\
& $(0.39)$ & $(0.19)$ & $(0.21)$ & \\
IT & $4.29^{* * *}$ & $1.31^{* * *}$ & 0.14 & 0.78 \\
& $(0.29)$ & $(0.06)$ & $(0.24)$ & \\
NL & $3.97^{* * *}$ & 0.11 & $0.81^{* * *}$ & 0.14 \\
& $(0.22)$ & $(0.25)$ & $(0.20)$ & \\
ES & $3.64^{* * *}$ & $1.46^{* * *}$ & $0.48^{*}$ & 0.70 \\
& $(0.36)$ & $(0.08)$ & $(0.27)$ & \\
PT & $3.50^{* * *}$ & $1.12^{* * *}$ & -0.39 & 0.85 \\
& $(0.50)$ & $(0.06)$ & $(0.33)$ & \\
\hline
\end{tabular}

Notes: Estimation for the period 1 Q1980 to 4Q2012, except for Greece, which is from 1Q1992 to 4Q2012. Dependent variable is the quarterly short-term interest rate. Equation (4) is estimated using a GMM estimator. $R^{2}$ is the determinant of coefficients for each country. ***, **, and * denote significance at the 1\%, 5\%, and 10\% levels, respectively 


\section{Appendix E. Explained Variance of Non-Fundamental House Prices by 1-Standard Deviation Monetary-Easing \\ Shock at $T=20$}

Table A5: Explained Variance of Non-Fundamental House Prices by 1-Standard Deviation Monetary-Easing Shock at $\mathrm{T}=20$

\begin{tabular}{|c|c|c|}
\hline & $\begin{array}{r}\text { High } \\
M_{i, t}=0.75\end{array}$ & $\begin{array}{r}\text { Low } \\
M_{i, t}=0.25\end{array}$ \\
\hline \multicolumn{3}{|c|}{ Model 4: Interest Rate Type } \\
\hline Core & $\begin{array}{r}1.78 \% \\
(0.003)\end{array}$ & $\begin{array}{r}0.78 \% \\
(0.001)\end{array}$ \\
\hline Periphery & $\begin{array}{r}2.93 \% \\
(0.004)\end{array}$ & $\begin{array}{r}1.09 \% \\
(0.002)\end{array}$ \\
\hline \multicolumn{3}{|c|}{ Model 5: Mortgage Equity Withdrawals } \\
\hline Core & $\begin{array}{r}0.97 \% \\
(0.001)\end{array}$ & $\begin{array}{r}1.51 \% \\
(0.001)\end{array}$ \\
\hline Periphery & $\begin{array}{l}36.49 \% \\
(0.101)\end{array}$ & $\begin{array}{r}3.01 \% \\
(0.003)\end{array}$ \\
\hline \multicolumn{3}{|c|}{ Model 6: Maximum LTV } \\
\hline Core & $\begin{array}{r}7.22 \% \\
(0.011)\end{array}$ & $\begin{array}{r}0.58 \% \\
(0.001)\end{array}$ \\
\hline Periphery & $\begin{array}{l}10.02 \% \\
(0.014)\end{array}$ & $\begin{array}{r}2.29 \% \\
(0.004)\end{array}$ \\
\hline \multicolumn{3}{|c|}{ Model 7: Securitization } \\
\hline Core & $\begin{array}{r}3.40 \% \\
(0.004)\end{array}$ & $\begin{array}{r}3.08 \% \\
(0.003)\end{array}$ \\
\hline Periphery & $\begin{array}{r}5.64 \% \\
(0.014)\end{array}$ & $\begin{array}{r}0.81 \% \\
(0.001)\end{array}$ \\
\hline \multicolumn{3}{|c|}{ Model 8: Government Participation } \\
\hline Core & $\begin{array}{r}8.38 \% \\
(0.011)\end{array}$ & $\begin{array}{r}3.88 \% \\
(0.004)\end{array}$ \\
\hline Periphery & $\begin{array}{r}6.96 \% \\
(0.019)\end{array}$ & $\begin{array}{r}1.28 \% \\
(0.002)\end{array}$ \\
\hline
\end{tabular}

Notes: The table shows the percent of explained variance of non-fundamental house price runups triggered by a 1-standard deviation monetary-easing shock. The absolute forecasted error variance (in bps) is in parentheses. The estimation period ranges from 1Q1992 to 2Q2007 based on Equation (5), with individual mortgage market characteristic interaction variables. We report results only when $M_{i, t}=0.75$ and $M_{i, t}=0.25$. 
Table A6: Explained Variance of Non-Fundamental House Prices by 1-Standard Deviation Monetary-Easing Shock at $\mathbf{T}=20$

\begin{tabular}{|c|c|c|}
\hline & $\begin{array}{r}\text { High } \\
M_{i, t}=0.75\end{array}$ & $\begin{array}{r}\text { Low } \\
M_{i, t}=0.25\end{array}$ \\
\hline \multicolumn{3}{|c|}{$\begin{array}{l}\text { Model 9: Alternative Fundamental Estimation: } \\
\text { Adding Dynamics }\end{array}$} \\
\hline Core & $\begin{array}{r}2.85 \% \\
(0.003)\end{array}$ & $\begin{array}{r}0.52 \% \\
(0.000)\end{array}$ \\
\hline Periphery & $\begin{array}{l}24.36 \% \\
(0.041)\end{array}$ & $\begin{array}{r}1.03 \% \\
(0.001)\end{array}$ \\
\hline \multicolumn{3}{|c|}{$\begin{array}{l}\text { Model 10: Alternative Fundamental Estimation: } \\
\text { Long-term deviation }\end{array}$} \\
\hline Core & $\begin{array}{r}9.66 \% \\
(0.432)\end{array}$ & $\begin{array}{r}5.48 \% \\
(0.101)\end{array}$ \\
\hline Periphery & $\begin{array}{l}15.16 \% \\
(0.573)\end{array}$ & $\begin{array}{r}4.47 \% \\
(0.070)\end{array}$ \\
\hline \multicolumn{3}{|c|}{$\begin{array}{l}\text { Model 11: Alternative Fundamental Estimation: } \\
\text { Price-to-Rent Ratio }\end{array}$} \\
\hline Core & $\begin{array}{r}0.32 \% \\
(0.072)\end{array}$ & $\begin{array}{r}5.82 \% \\
(1.402)\end{array}$ \\
\hline Periphery & $\begin{array}{r}16.85 \% \\
(55.583)\end{array}$ & $\begin{array}{r}0.38 \% \\
(0.715)\end{array}$ \\
\hline \multicolumn{3}{|c|}{ Model 12: Alternative Taylor Rate Estimation } \\
\hline Core & $\begin{array}{r}1.00 \% \\
(0.001)\end{array}$ & $\begin{array}{r}2.42 \% \\
(0.002)\end{array}$ \\
\hline Periphery & $\begin{array}{l}20.48 \% \\
(0.035)\end{array}$ & $\begin{array}{r}2.43 \% \\
(0.003)\end{array}$ \\
\hline \multicolumn{3}{|c|}{ Model 13: Constant Maximum LTV } \\
\hline Core & $\begin{array}{r}7.72 \% \\
(0.012)\end{array}$ & $\begin{array}{r}0.49 \% \\
(0.000)\end{array}$ \\
\hline Periphery & $\begin{array}{r}4.77 \% \\
(0.007)\end{array}$ & $\begin{array}{r}3.85 \% \\
(0.005)\end{array}$ \\
\hline \multicolumn{3}{|c|}{ Model 14: Exogenous IR Shock } \\
\hline Core & $\begin{array}{r}2.57 \% \\
(0.003)\end{array}$ & $\begin{array}{r}0.32 \% \\
(0.000)\end{array}$ \\
\hline Periphery & $\begin{array}{r}20.99 \% \\
(0.037)\end{array}$ & $\begin{array}{r}2.25 \% \\
(0.002)\end{array}$ \\
\hline
\end{tabular}

Notes: The table shows the percent of explained variance of non-fundamental house price runups triggered by a 1-standard deviation monetary-easing shock. The absolute forecasted error variance (in bps) is in parentheses. We report the results only for when $M_{i, t}=0.75$ and $M_{i, t}=0.25$. 


\section{Appendix F. House Price Changes and Fundamental Changes (Online Appendix)}

Figure A1: House Price Changes and Fundamental Changes
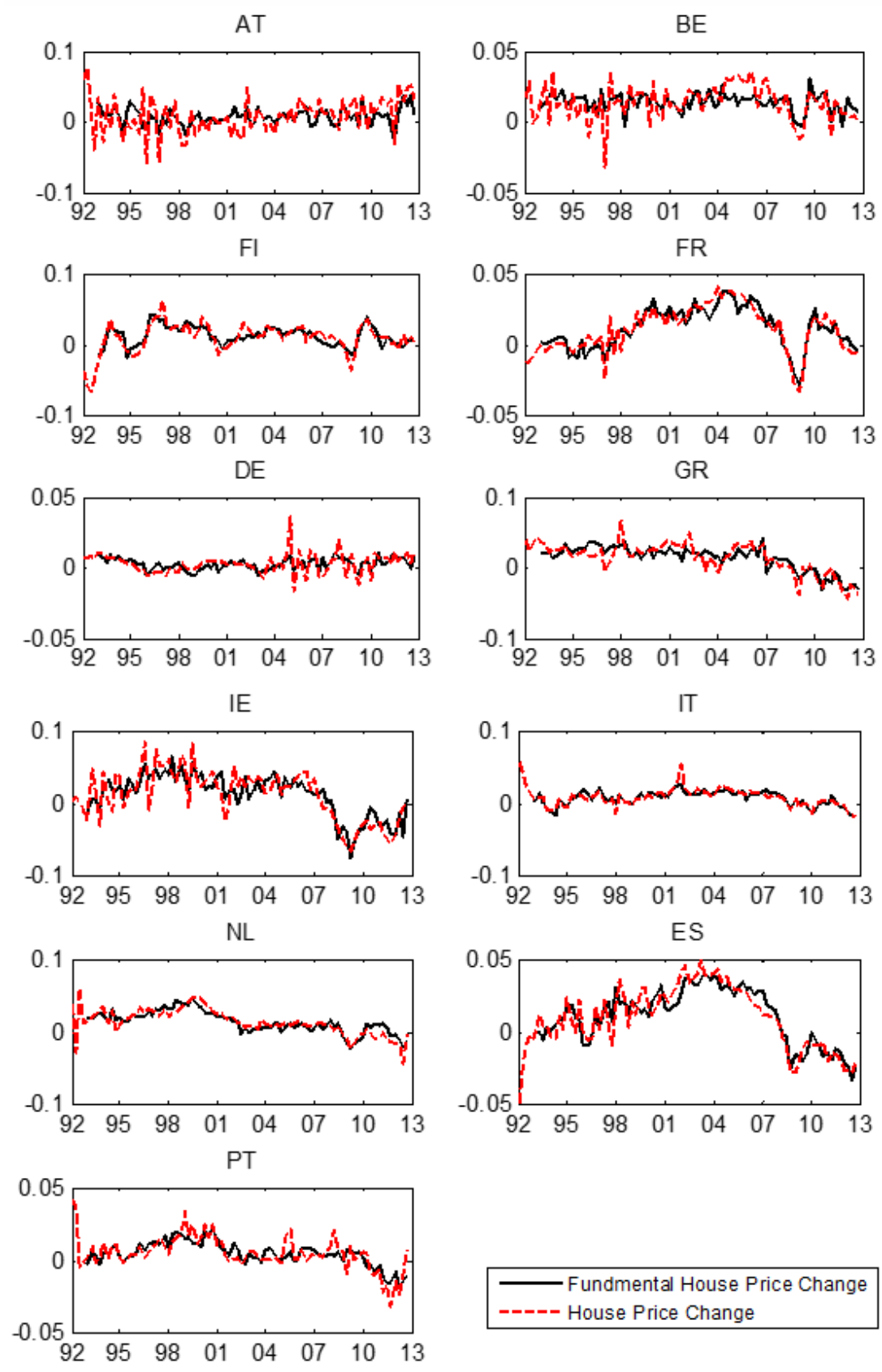

Fundmental House Price Change ----- House Price Change 


\section{Appendix G. Interest Rate and Estimated Taylor Rate (Online Appendix)}

Figure A2: Interest Rate and Estimated Taylor Rate
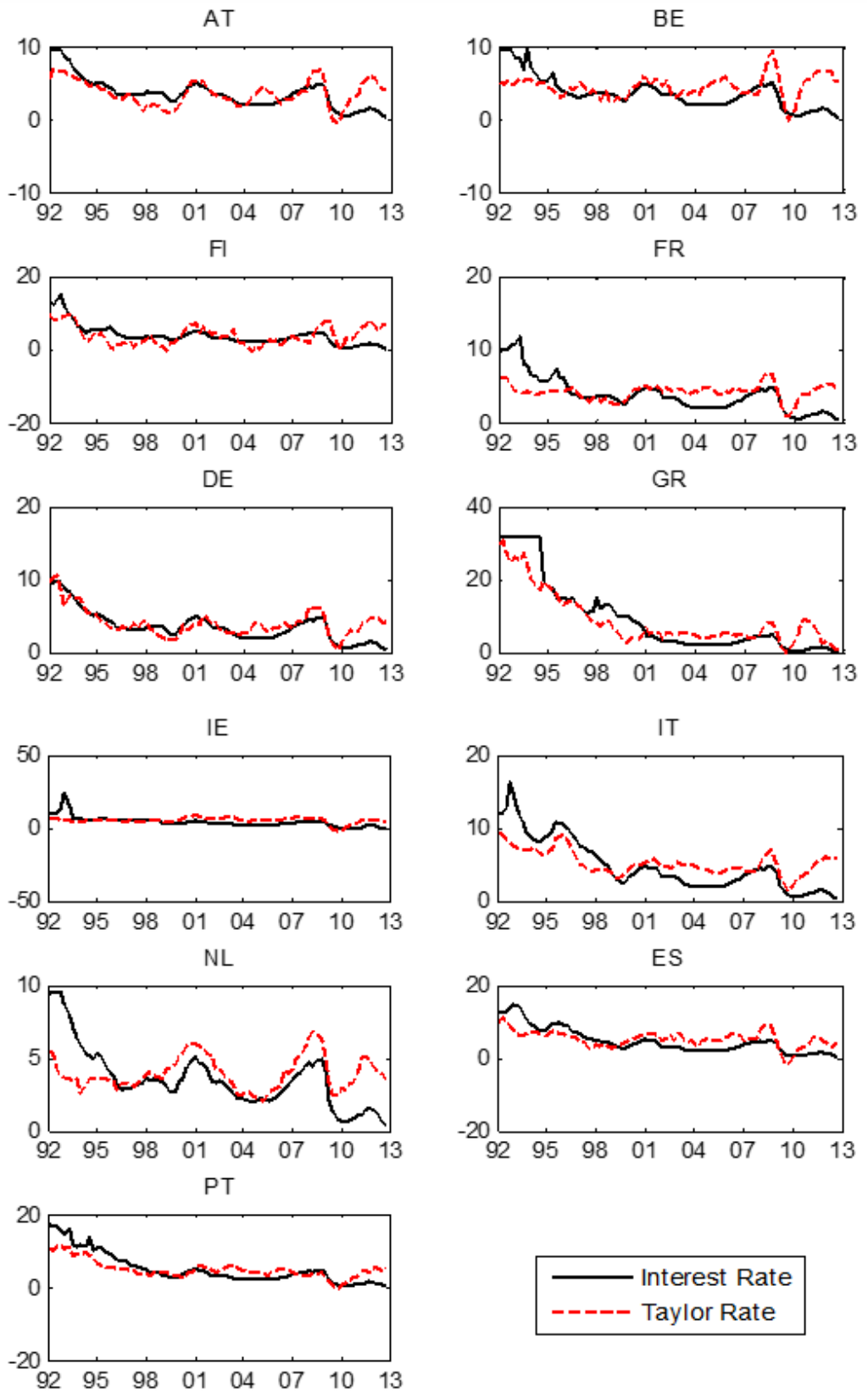

Interest Rate ----- Taylor Rate 


\section{Appendix H. Robustness Tests (Online Appendix)}

Figure A3: Robustness Tests
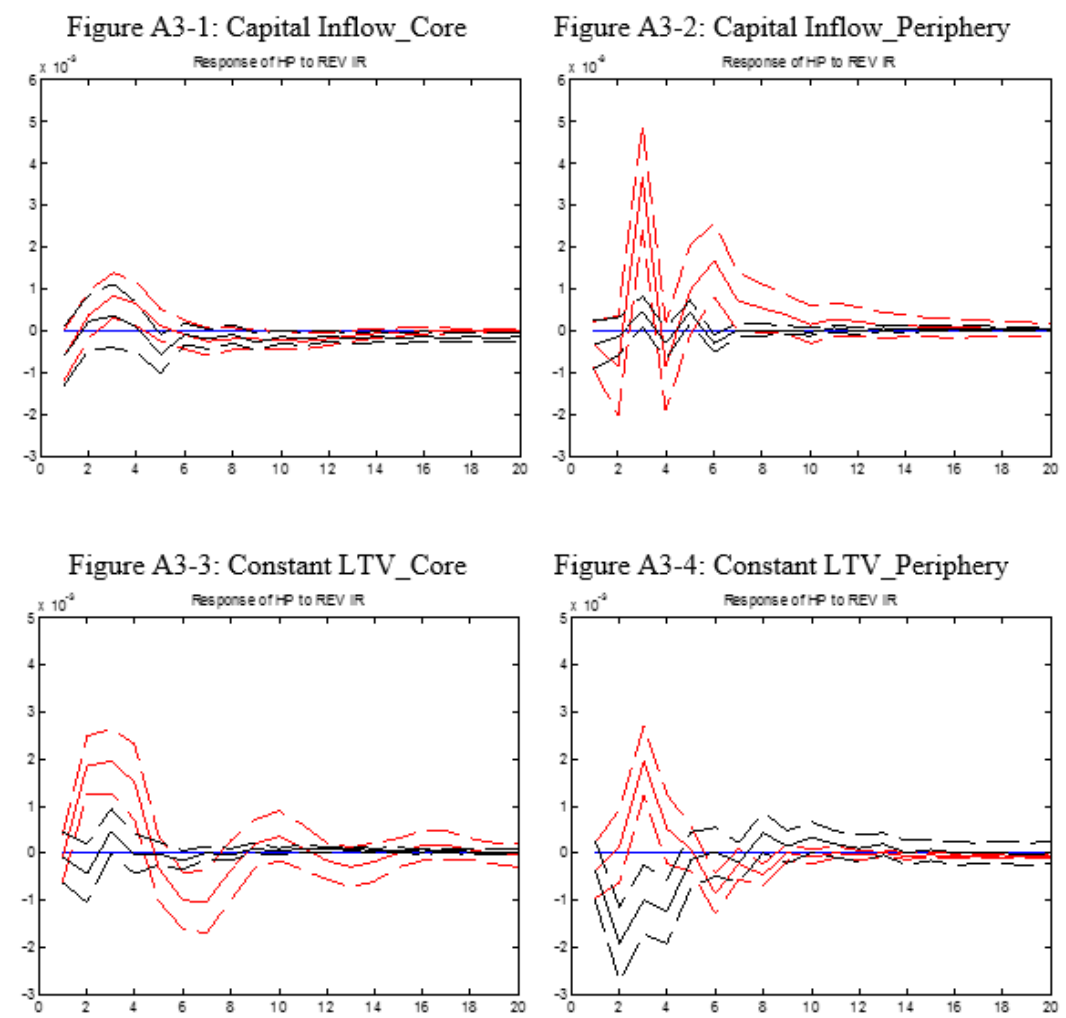

Figure A3-4: Constant LTV_Periphery

Figure A3-5: Exogenous IR_Core
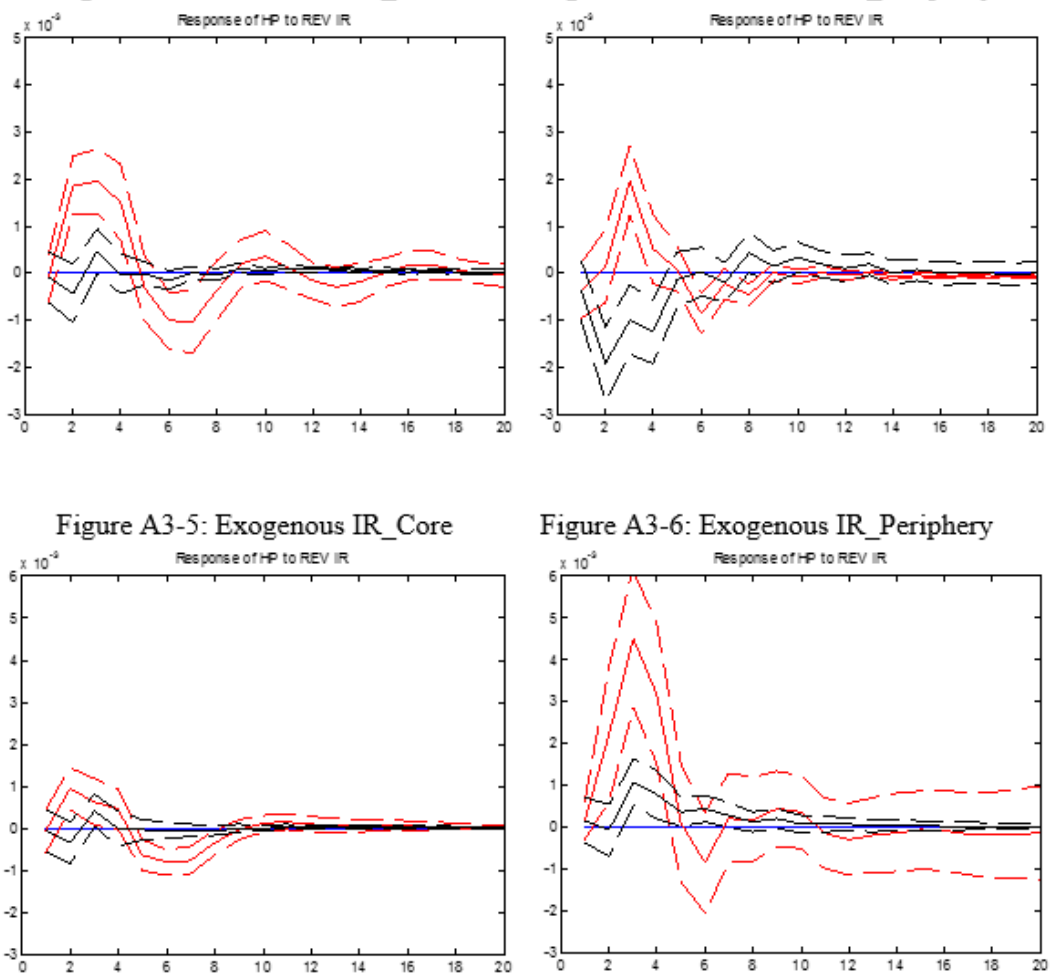

Notes: The graphs show the responses of non-fundamental house prices to a 1-standard deviation positive shock to the reverse of interest rates (monetary easing). Red solid lines show the response in the developed mortgage market $\left(M_{i, t}=0.75\right)$; red dotted lines show the upper and lower bounds for bootstrapped 90\% confidence intervals to the corresponding responses. Black solid lines show the responses in less developed mortgage markets $\left(M_{i, t}=0.25\right)$; black dotted lines show the upper and lower bounds for bootstrapped 90\% confidence intervals to the corresponding responses. 
Table 1: Structural Break Test

\begin{tabular}{lc}
\hline & Chow Test \\
\hline Model 1: 11 Euro Area Countries & $2.57^{* * *}$ \\
Model 2: 6 Core Area Countries & $1.31^{* * *}$ \\
Model 3: 5 Peripheral Countries & $2.18^{* * *}$ \\
\hline
\end{tabular}


Table 2: Explained Variance of Non-Fundamental House Price by 1-Standard Deviation Monetary-Easing Shock at $T=20$

\begin{tabular}{|c|c|c|}
\hline & $\begin{array}{r}\text { High } \\
M_{i, t}=0.75\end{array}$ & $M_{i, t}=0.25$ \\
\hline \multicolumn{3}{|l|}{ Model 1: 11 EU Countries } \\
\hline REV IR shock to NF HP & $\begin{array}{r}7.38 \% \\
(0.010)\end{array}$ & $\begin{array}{r}0.39 \% \\
(0.000)\end{array}$ \\
\hline Credit shock to NF HP & $\begin{array}{r}2.50 \% \\
(0.003)\end{array}$ & $\begin{array}{r}1.89 \% \\
(0.002)\end{array}$ \\
\hline Capital inflow shock to NF HP & $\begin{array}{r}3.62 \% \\
(0.005)\end{array}$ & $\begin{array}{r}0.64 \% \\
(0.001)\end{array}$ \\
\hline Sentiment shock to NF HP & $\begin{array}{r}1.73 \% \\
(0.002)\end{array}$ & $\begin{array}{r}0.37 \% \\
(0.000)\end{array}$ \\
\hline NF HP shock to NF HP & $\begin{array}{l}84.77 \% \\
(0.111)\end{array}$ & $\begin{array}{l}96.70 \% \\
(0.107)\end{array}$ \\
\hline \multicolumn{3}{|l|}{ Model 2: 6 Core Countries } \\
\hline REV IR shock to NF HP & $\begin{array}{r}2.32 \% \\
(0.003)\end{array}$ & $\begin{array}{r}0.39 \% \\
(0.000)\end{array}$ \\
\hline Credit shock to NF HP & $\begin{array}{r}1.63 \% \\
(0.002)\end{array}$ & $\begin{array}{r}3.25 \% \\
(0.003)\end{array}$ \\
\hline Capital inflow shock to NF HP & $\begin{array}{r}1.50 \% \\
(0.002)\end{array}$ & $\begin{array}{r}1.23 \% \\
(0.001)\end{array}$ \\
\hline Sentiment shock to NF HP & $\begin{array}{r}3.88 \% \\
(0.005)\end{array}$ & $\begin{array}{r}0.88 \% \\
(0.001)\end{array}$ \\
\hline NF HP shock to NF HP & $\begin{array}{l}90.67 \% \\
(0.117)\end{array}$ & $\begin{array}{l}94.25 \% \\
(0.095)\end{array}$ \\
\hline \multicolumn{3}{|c|}{ Model 3: 5 Peripheral countries } \\
\hline REV IR shock to NF HP & $\begin{array}{r}24.36 \% \\
(0.041)\end{array}$ & $\begin{array}{r}1.03 \% \\
(0.001)\end{array}$ \\
\hline Credit shock to NF HP & $\begin{array}{r}4.31 \% \\
(0.007)\end{array}$ & $\begin{array}{r}3.00 \% \\
(0.003)\end{array}$ \\
\hline Capital inflow shock to NF HP & $\begin{array}{r}9.26 \% \\
(0.016)\end{array}$ & $\begin{array}{r}0.84 \% \\
(0.001)\end{array}$ \\
\hline Sentiment shock to NF HP & $\begin{array}{r}3.08 \% \\
(0.005)\end{array}$ & $\begin{array}{r}0.75 \% \\
(0.001)\end{array}$ \\
\hline NF HP shock to NF HP & $\begin{array}{l}58.99 \% \\
(0.100)\end{array}$ & $\begin{array}{l}94.39 \% \\
(0.092)\end{array}$ \\
\hline
\end{tabular}

Notes: This table shows the percent of explained variance of non-fundamental house price runups triggered by a 1-standard deviation monetary-easing shock. The absolute forecasted error variance (in bps) is in parentheses. The estimation period ranges from 1Q1992 to 2Q2007 based on Equation (5), using the individual mortgage market development indicator as the interaction variable. We only report results for $M_{i, t}=0.75$ and $M_{i, t}=0.25$. 
Figure 1: Maximum Cumulative Percentage Deviation from Fundamental Values

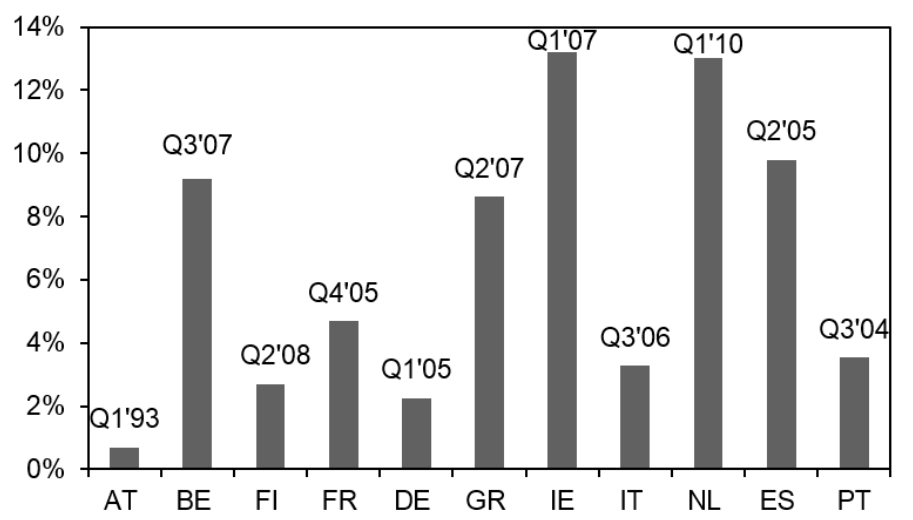

Notes: The graph shows the maximum cumulative deviation of house prices from fundamental values for eleven Euro area countries from 1Q1992 through 4Q2012. The label shows the quarter when the maximum cumulative deviation occurred.

Figure 2: Average Interest Rate Gaps

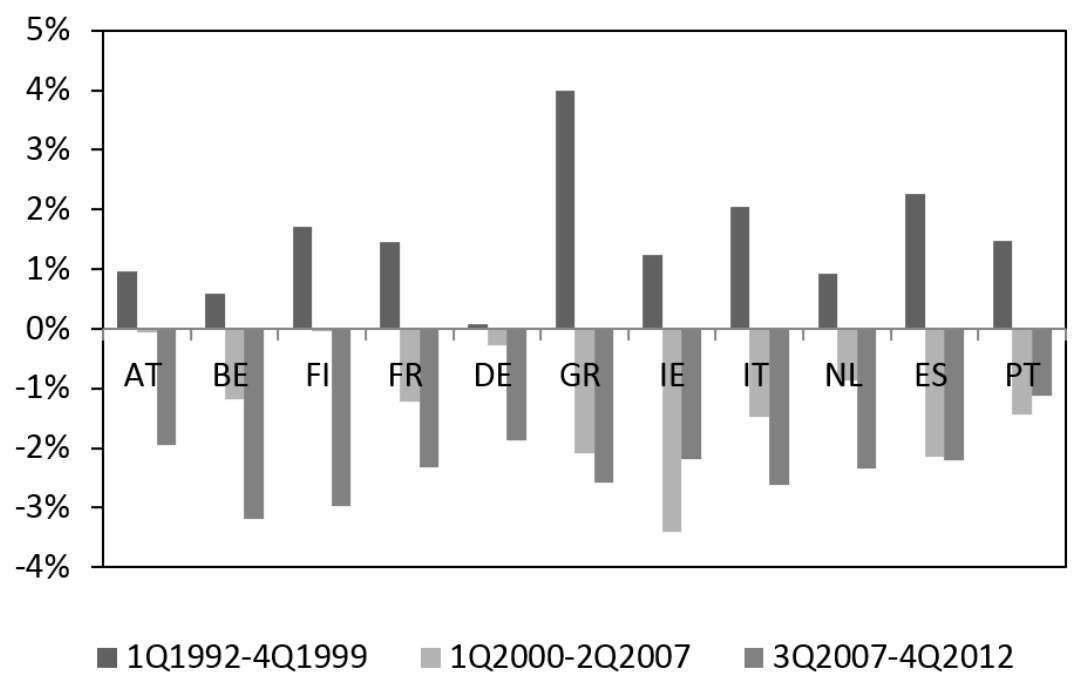

Notes: The graph shows the average differences between the short-term interest rate and the Taylor rule rate for eleven countries during three periods: 1Q1992-4Q1999, 1Q2000-2Q2007, and 3Q20074Q2012. The three stages for Greece are: 1Q1992-4Q2000, 1Q2001-2Q2007, and 3Q2007-4Q2012. 


\section{Figure 3: Impact of 1-Standard Deviation Interest Rate-Easing Shock on Non- Fundamental House Prices in Countries with More (Red) or Less Developed Mortgage Markets (Black)}

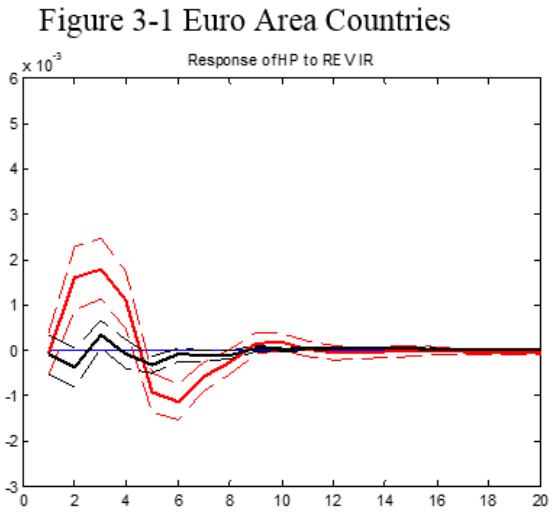

Figure 3-2 Core Countries

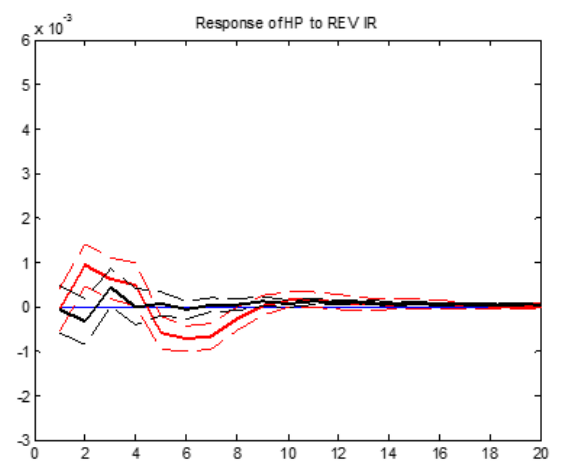

Figure 3-3 Peripheral Countries

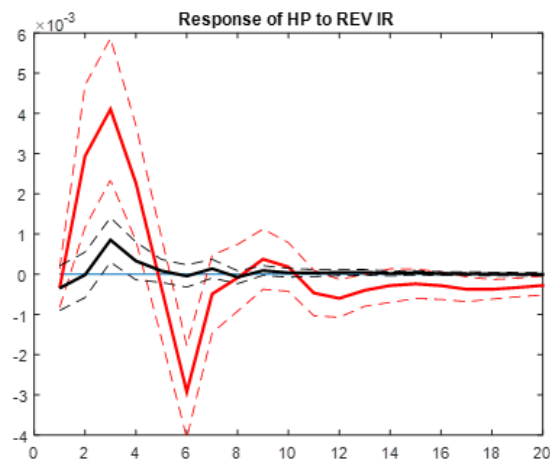

Notes: The estimation period ranges from 1Q1992 to 2Q200\%. The graphs show the responses of a non-fundamental house price to a 1-standard deviation positive shock to the reverse of the interest rate (monetary-easing). Red solid lines show the response in the developed mortgage market $\left(M_{i, t}=0.75\right)$; red dotted lines show the upper and lower bounds for bootstrapped $90 \%$ confidence intervals to the corresponding responses. Black solid lines show the response in less developed mortgage markets $\left(M_{i, t}=0.25\right)$; black dotted lines show the upper and lower bounds for bootstrapped 90\% confidence intervals to the corresponding responses. 
Figure 4: Impact of Interest Rate Gap on Non-Fundamental House Price Changes in Eleven Euro Area Countries in the 2000s

Figure 4-1: Cumulative Response

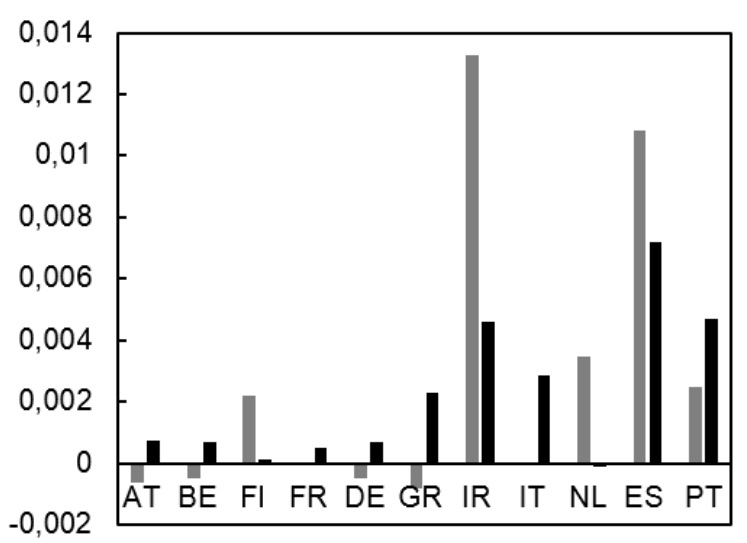

Figure 4-2: Explained Variance

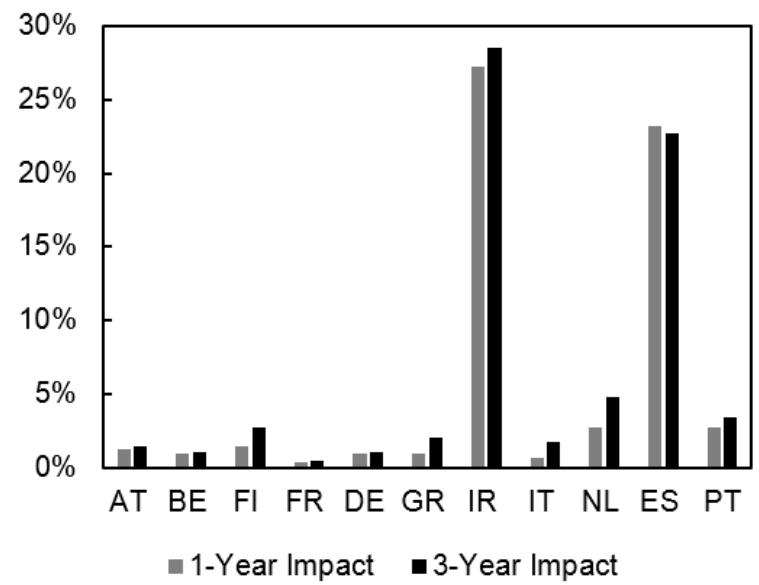

Figure 5: Counterfactual Monetary Policy Stance for GIIPS
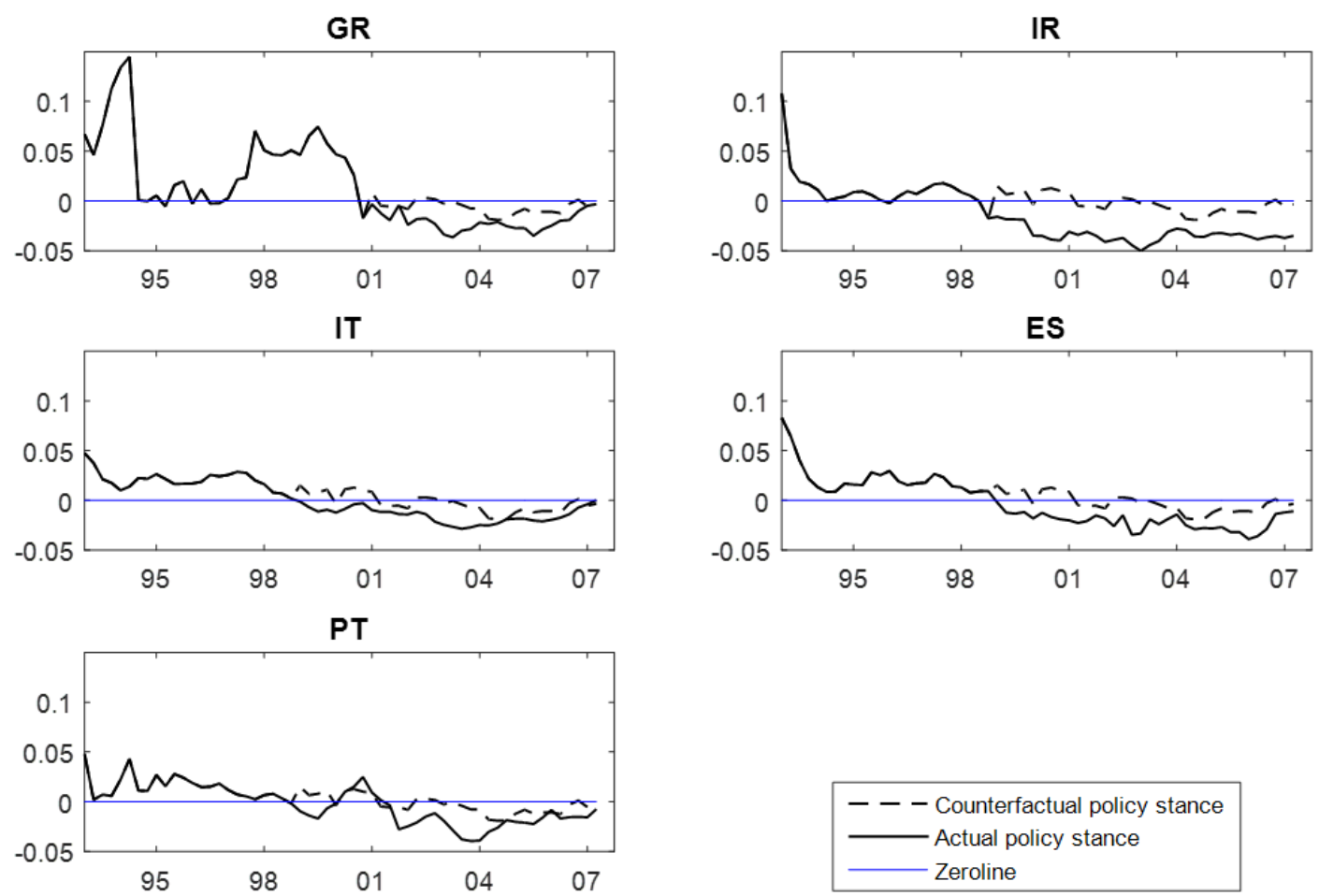
Figure 6: Simulated House Prices in GIIPS using Counterfactual Monetary Policy Stances but Actual Mortgage Market Regulations
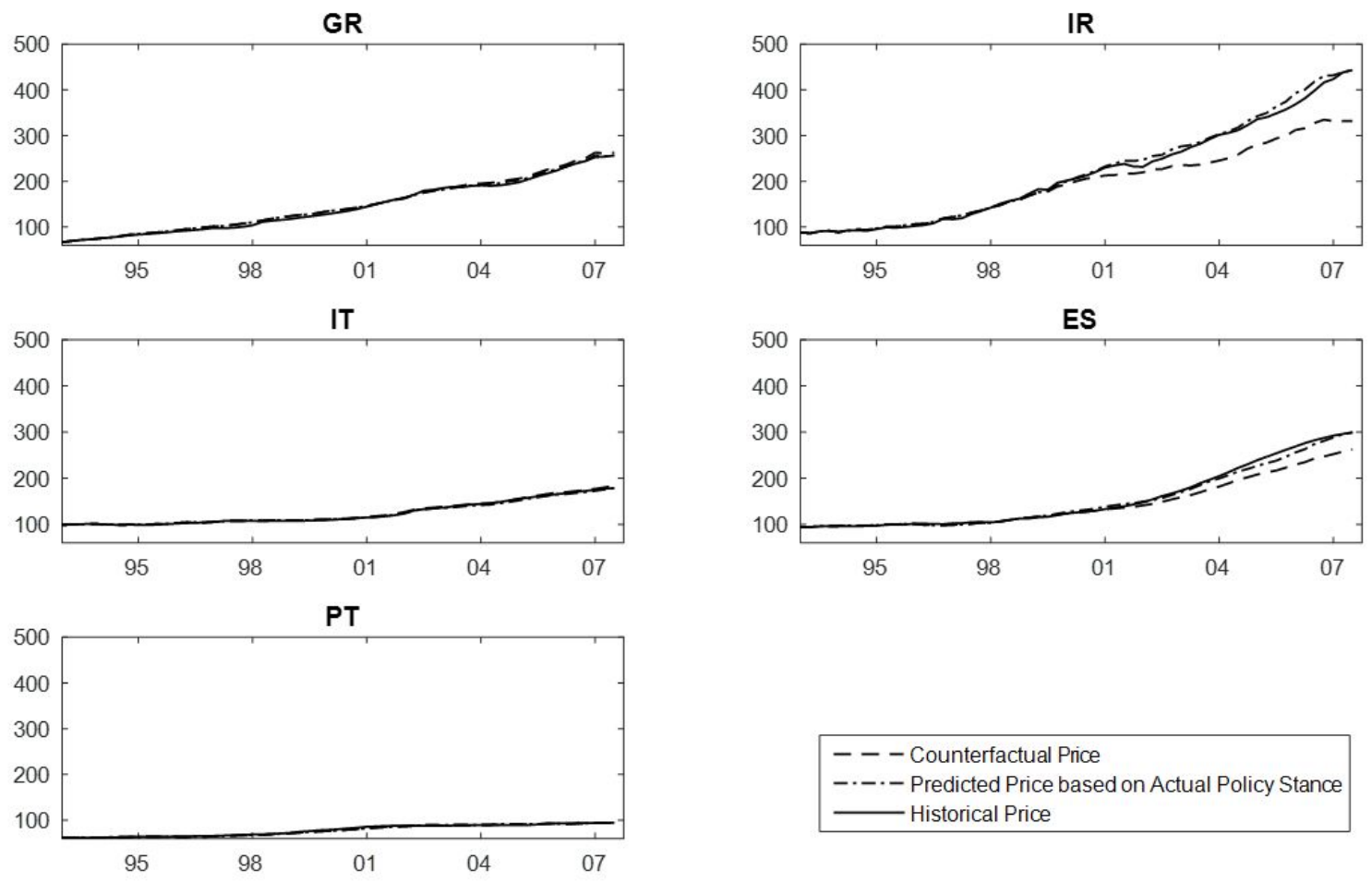
Figure 7: Simulated House Prices using Counterfactual Mortgage Market Regulations but Actual Policy Stances
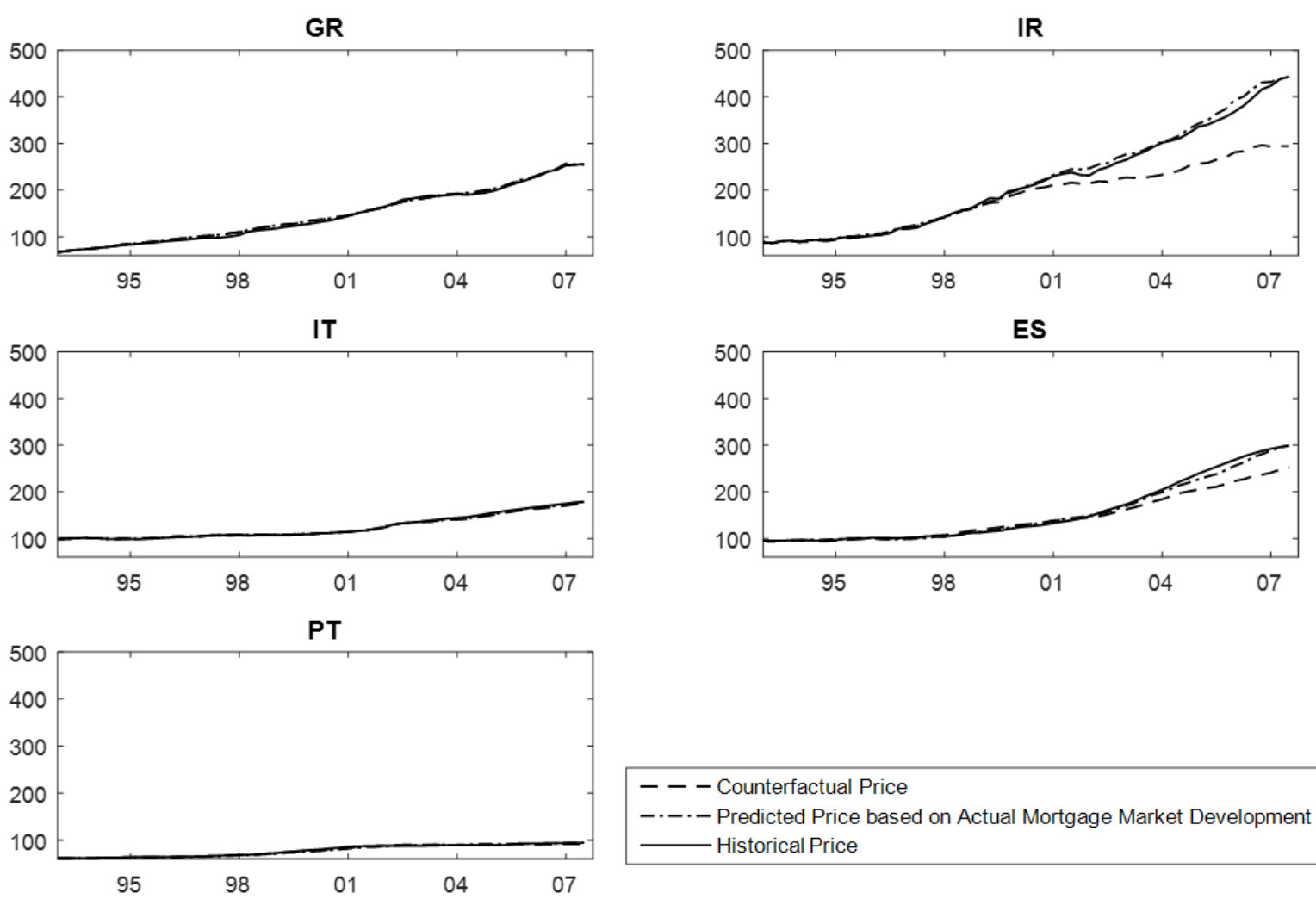

- - - Counterfactual Price

-.-.- Predicted Price based on Actual Mortgage Market Development - Historical Price 


\section{Figure 8: Impact of Interest Rate Type on Responses to Monetary Impulse}

\section{Core}

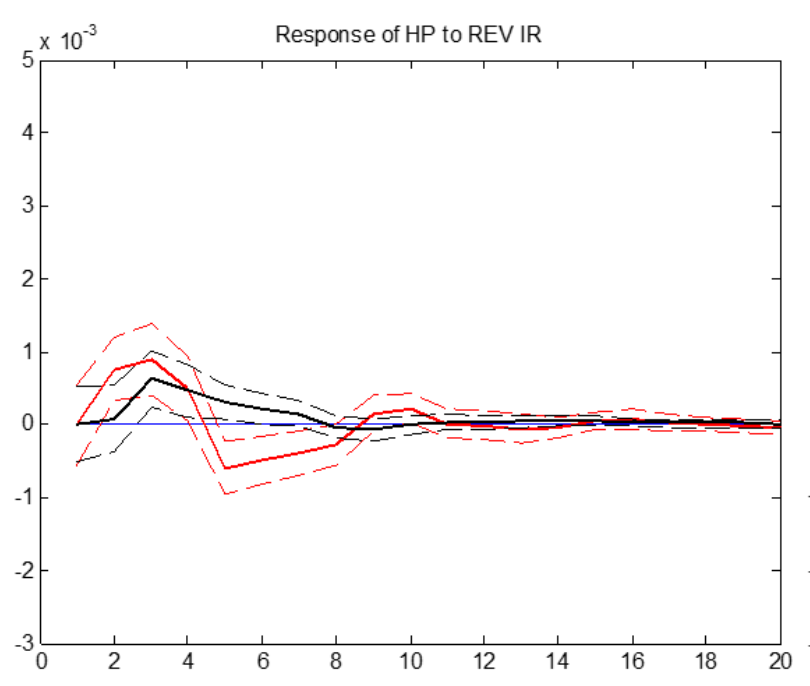

\section{Periphery}

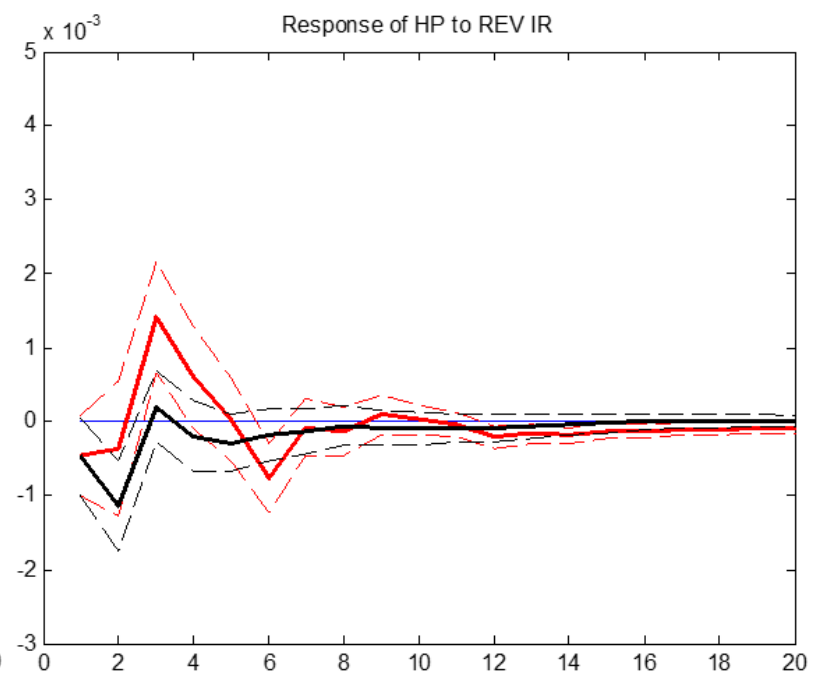

Notes: The estimation period ranges from 1Q1992 to 2Q200\%. The graphs show the responses of non-fundamental house prices to a 1-standard deviation positive shock to the reverse of interest rates (monetary easing). Red solid lines show the response in the mortgage market with variable mortgage rates $\left(M_{i, t}^{M R}=0.75\right)$; red dotted lines show the upper and lower bounds for bootstrapped 90\% confidence intervals to the corresponding responses. Black solid lines show the response in less developed mortgage markets, i.e., those with predominantly fixed mortgage rates $\left(M_{i, t}^{M R}=0.25\right)$; black dotted lines show the upper and lower bounds for bootstrapped $90 \%$ confidence intervals to the corresponding responses. 


\section{Figure 9: Impact of MEW on Responses to Monetary Impulse}
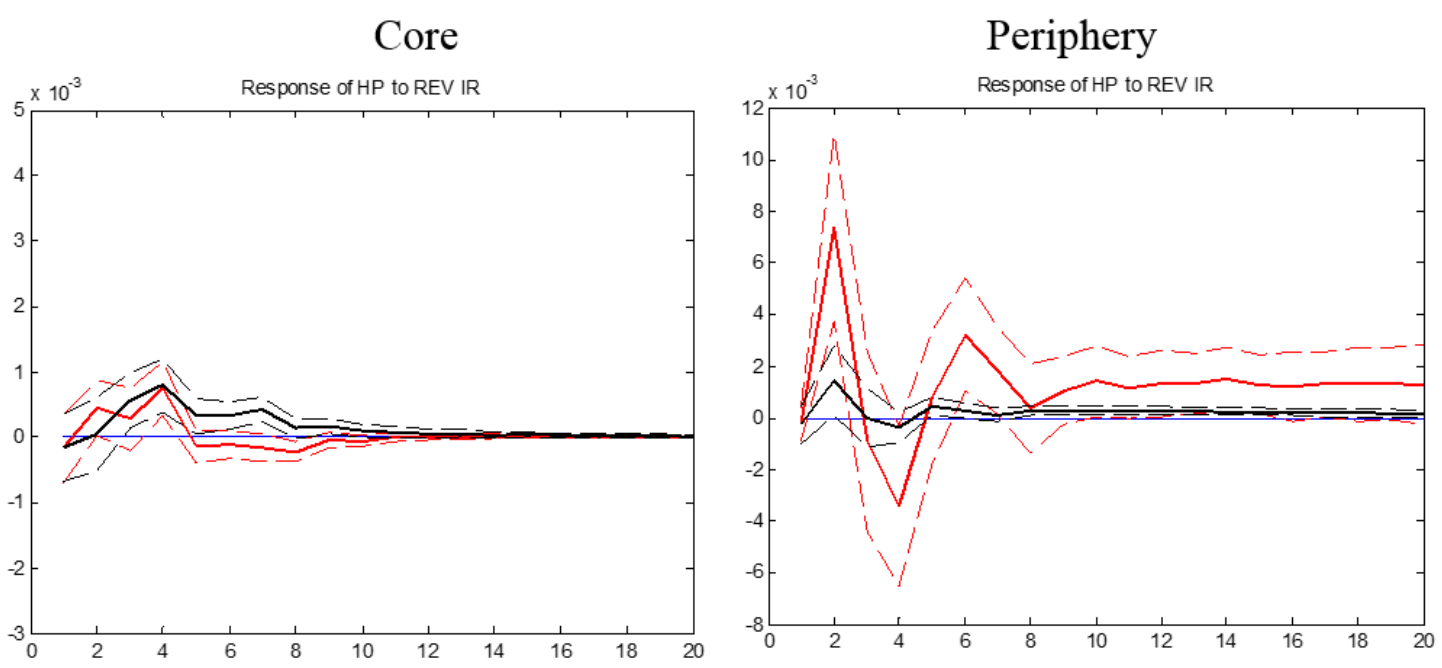

Notes: The estimation period ranges from 1Q1992 to 2Q200\%. The graphs show the responses of non-fundamental house prices to a 1-standard deviation positive shock to the reverse of interest rates (monetary easing). Red solid lines show the response in the mortgage market with MEW $\left(M_{i, t}^{M E W}=0.75\right)$; red dotted lines show the upper and lower bounds for bootstrapped $90 \%$ confidence intervals to the corresponding responses. Black solid lines show the response in less developed mortgage markets, i.e., those with limited $M E W\left(M_{i, t}^{M E W}=0.25\right)$; black dotted lines show the upper and lower bounds for bootstrapped $90 \%$ confidence intervals to the corresponding responses. 
Figure 10: Impact of LTV on Responses to Monetary Impulse

\section{Core}

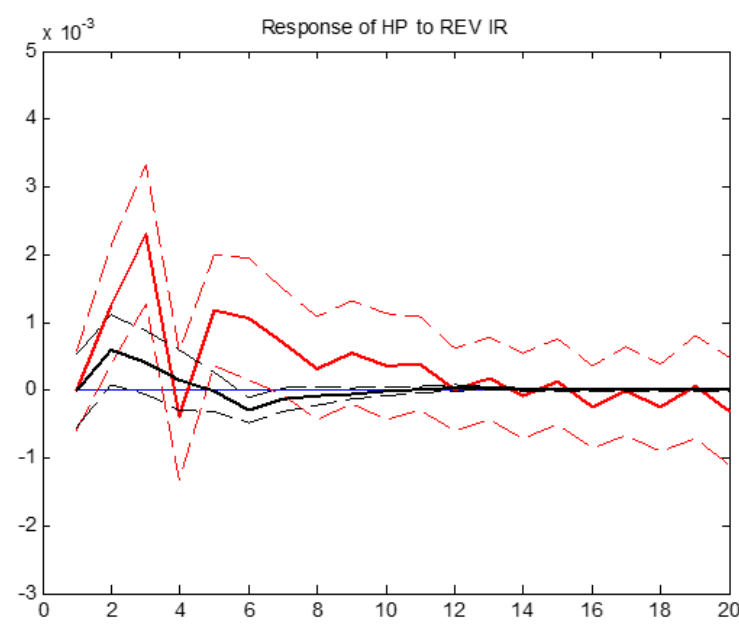

Periphery

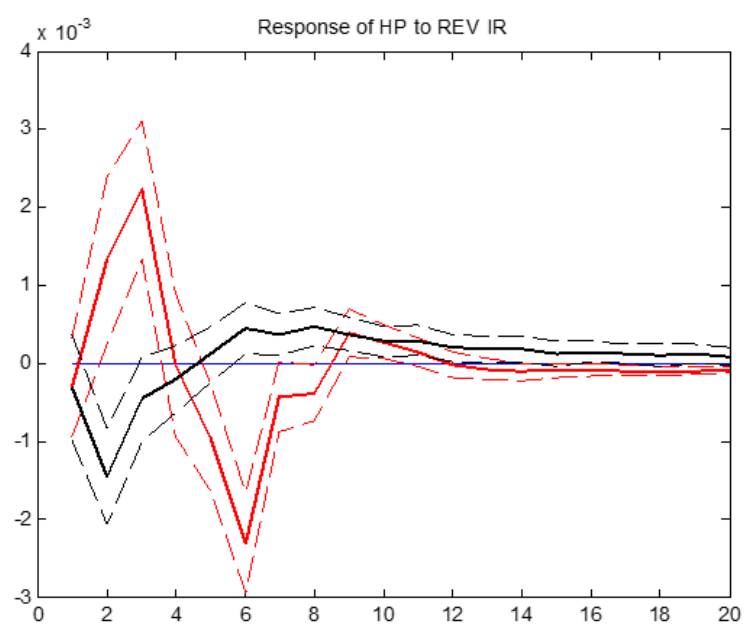

Notes: The estimation period ranges from 1Q1992 to 2Q200\%. The graphs show the responses of non-fundamental house prices to a 1-standard deviation positive shock to the reverse of interest rates (monetary easing). Red solid lines show the responses in the mortgage market with a high LTV $\left(M_{i, t}^{L T V}=0.75\right)$; red dotted lines show the upper and lower bounds for bootstrapped $90 \%$ confidence intervals to the corresponding responses. Black solid lines show the responses in less developed mortgage markets, i.e., those with a low LTV $\left(M_{i, t}^{L T V}=0.25\right)$; black dotted lines show the upper and lower bounds for bootstrapped $90 \%$ confidence intervals to the corresponding responses. 


\section{Figure 11: Impact of MS on Responses to Monetary Impulse}
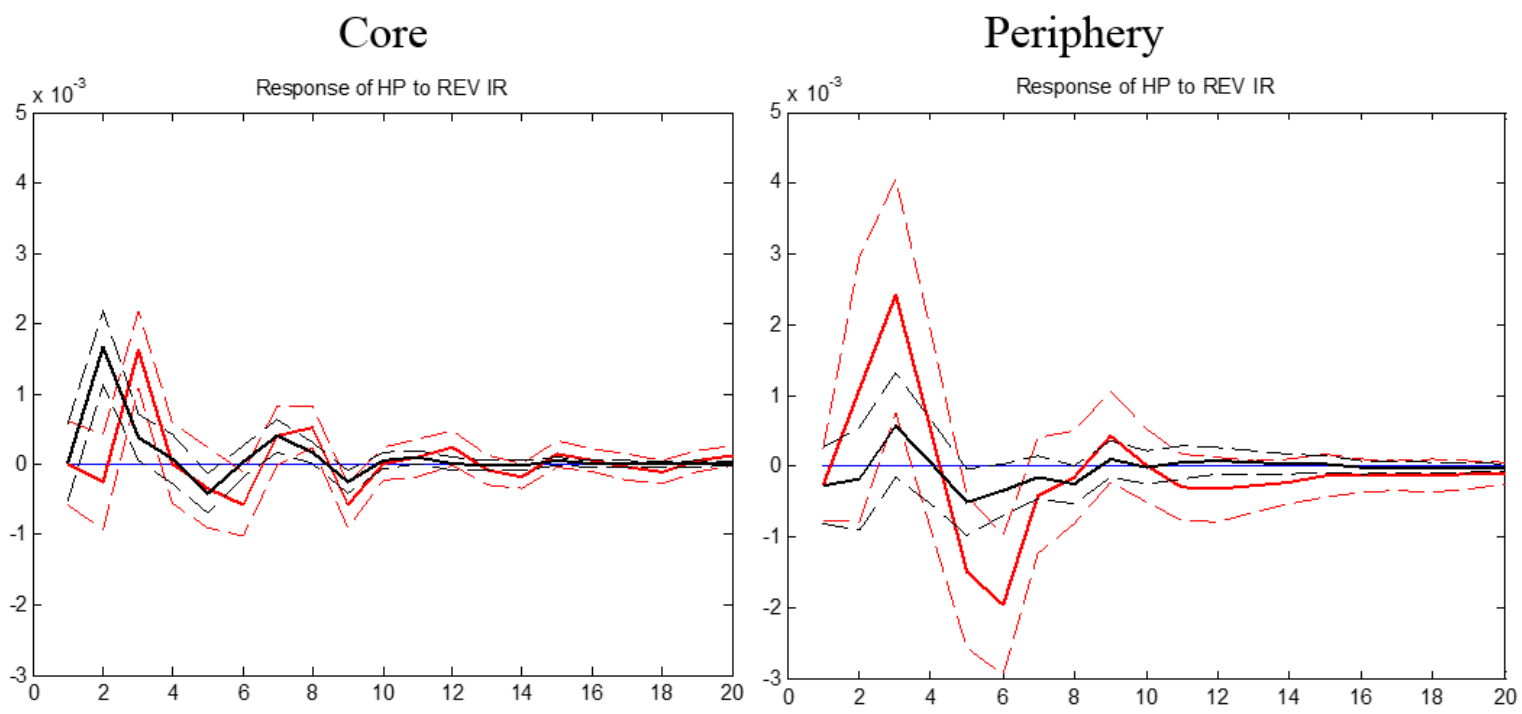

Notes: The estimation period ranges from 1Q1992 to 2Q200\%. The graphs show the responses of non-fundamental house prices to a 1-standard deviation positive shock to the reverse of interest rates (monetary easing). Red solid lines show the response in the mortgage markets with a high degree of $M S\left(M_{i, t}^{M S}=0.75\right)$; red dotted lines show the upper and lower bounds for bootstrapped 90\% confidence intervals to the corresponding responses. Black solid lines show the responses in less developed mortgage markets, i.e., those with limited $M S\left(M_{i, t}^{M S}=0.25\right)$; black dotted lines show the upper and lower bounds for bootstrapped 90\% confidence intervals to the corresponding responses. 


\section{Figure 12: Impact of GP on Responses to Monetary Impulse}

\section{Core}

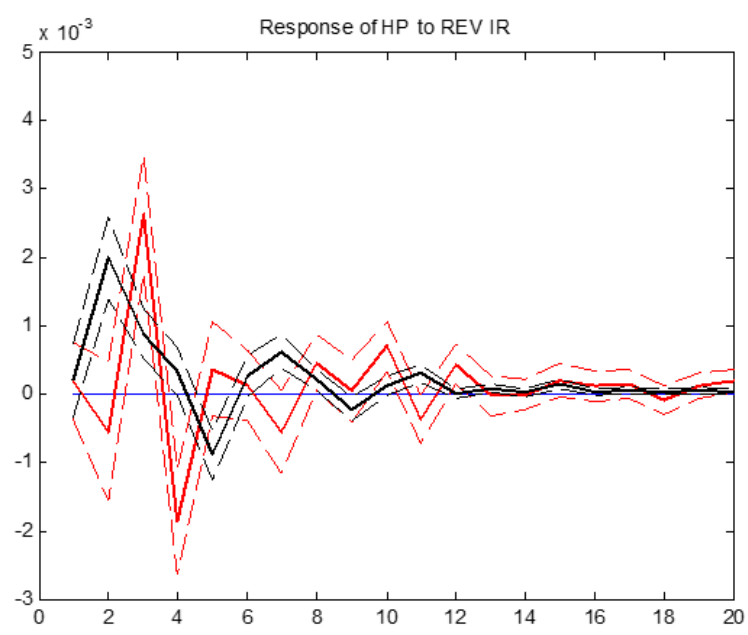

Periphery

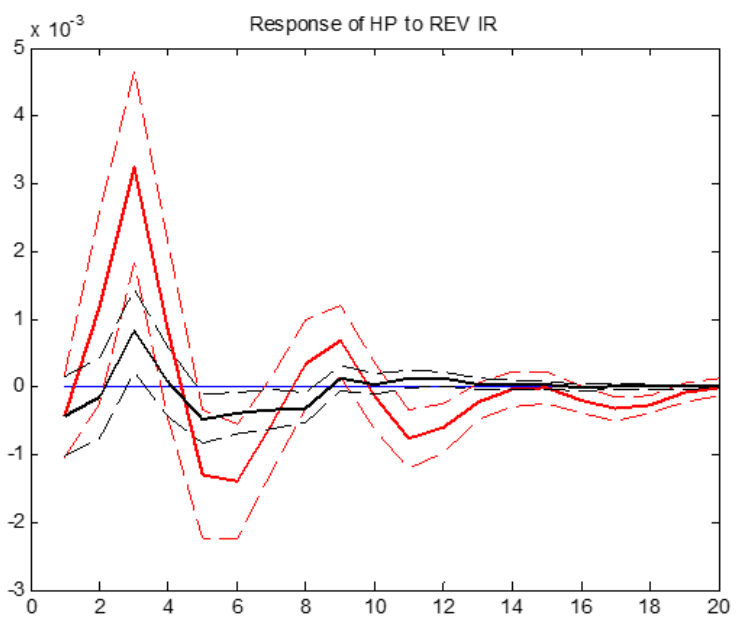

Notes: The estimation period ranges from 1Q1992 to 2Q200\%. The graphs show the responses of non-fundamental house prices to a 1-standard deviation positive shock to the reverse of interest rates (monetary easing). Red solid lines show the responses in the mortgage markets with a high level of GP $\left(M_{i, t}^{G P}=0.75\right)$; red dotted lines show the upper and lower bounds for bootstrapped $90 \%$ confidence intervals to the corresponding responses. Black solid lines show the responses in less developed mortgage markets, i.e., those with a low level of $G P\left(M_{i, t}^{G P}=0.25\right)$; black dotted lines show the upper and lower bounds for bootstrapped 90\% confidence intervals to the corresponding responses. 
Figure 13: Alternative Measures of Non-fundamental Price Runups: Adding Dynamics

Core

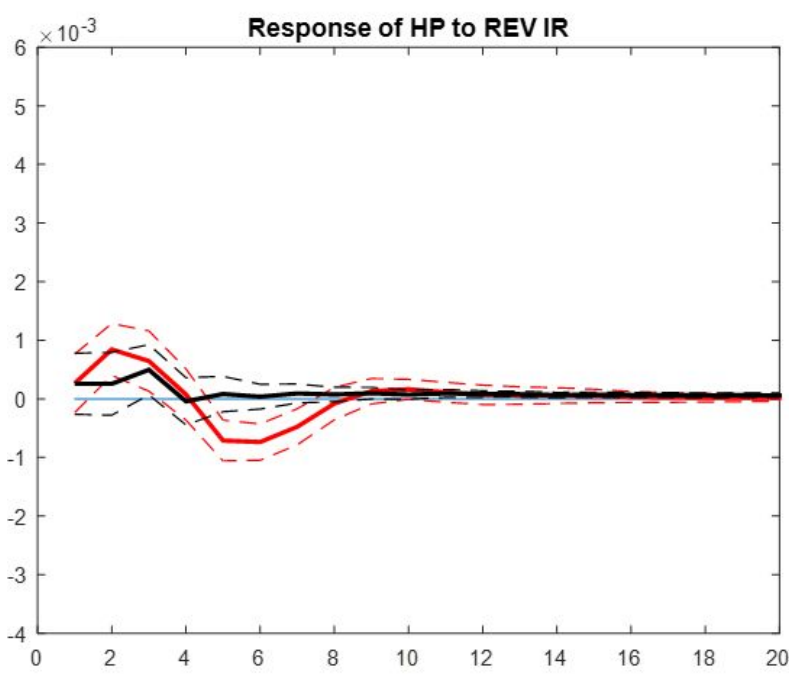

Periphery

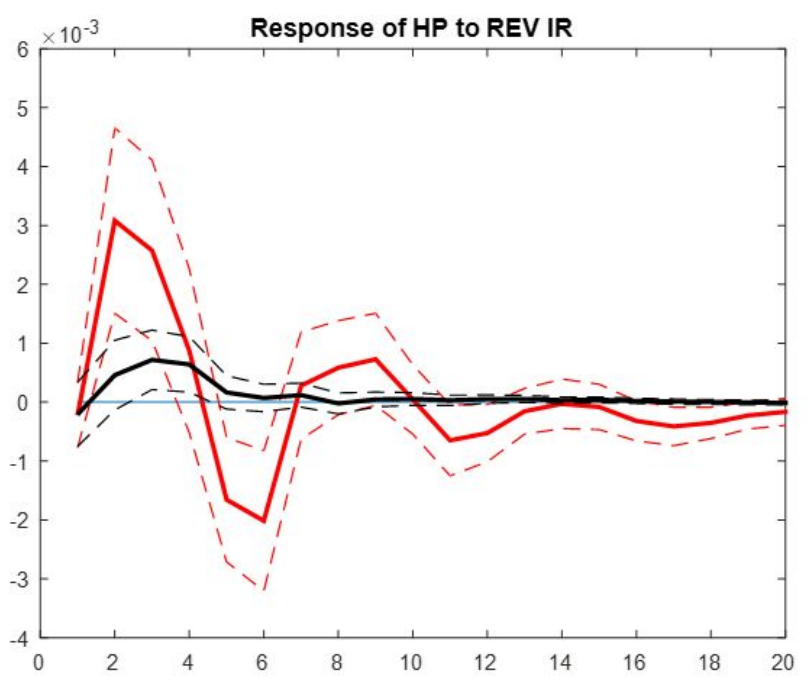

Notes: The estimation period ranges from 1Q1992 to 2Q200\%. The graphs show the responses of non-fundamental house prices to a 1-standard deviation positive shock to the reverse of the interest rate (monetary easing). Red solid lines show the responses in the mortgage market $\left(M_{i, t}=0.75\right)$; red dotted lines show the upper and lower bounds for bootstrapped $90 \%$ confidence intervals to the corresponding responses. Black solid lines show the response in less developed mortgage markets $\left(M_{i, t}=0.25\right)$; black dotted lines show the upper and lower bounds for bootstrapped $90 \%$ confidence intervals to the corresponding responses. 
Figure 14: Alternative Measures of Non-fundamental Price Runups: Equilibrium Trend
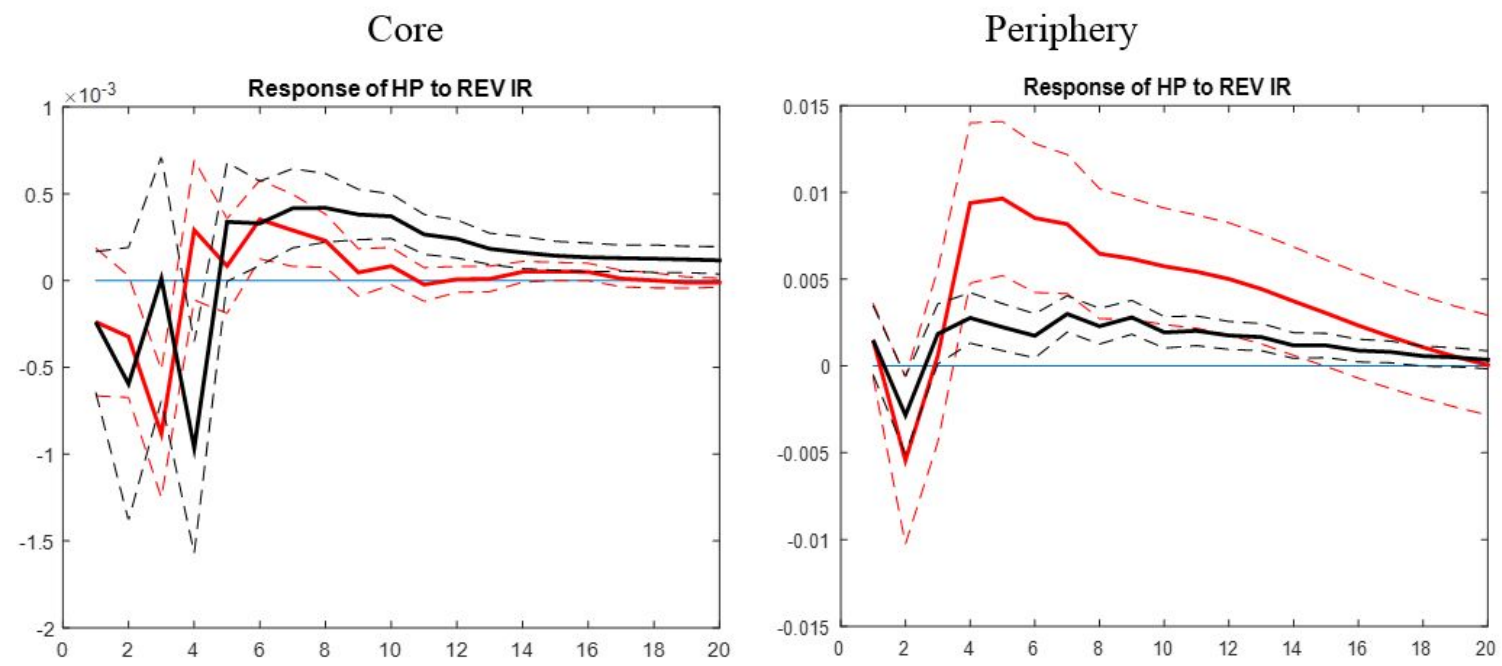

Notes: The estimation period ranges from 1Q1992 to 2Q200\%. The graphs show the responses of non-fundamental house prices to a 1-standard deviation positive shock to the reverse of the interest rate (monetary easing). Red solid lines show the responses in the mortgage market $\left(M_{i, t}=0.75\right)$; red dotted lines show the upper and lower bounds for bootstrapped $90 \%$ confidence intervals to the corresponding responses. Black solid lines show the response in less developed mortgage markets $\left(M_{i, t}=0.25\right)$; black dotted lines show the upper and lower bounds for bootstrapped 90\% confidence intervals to the corresponding responses. 
Figure 15: Alternative Measures of Non-fundamental Price Runups: Price-to-Rent Ratio
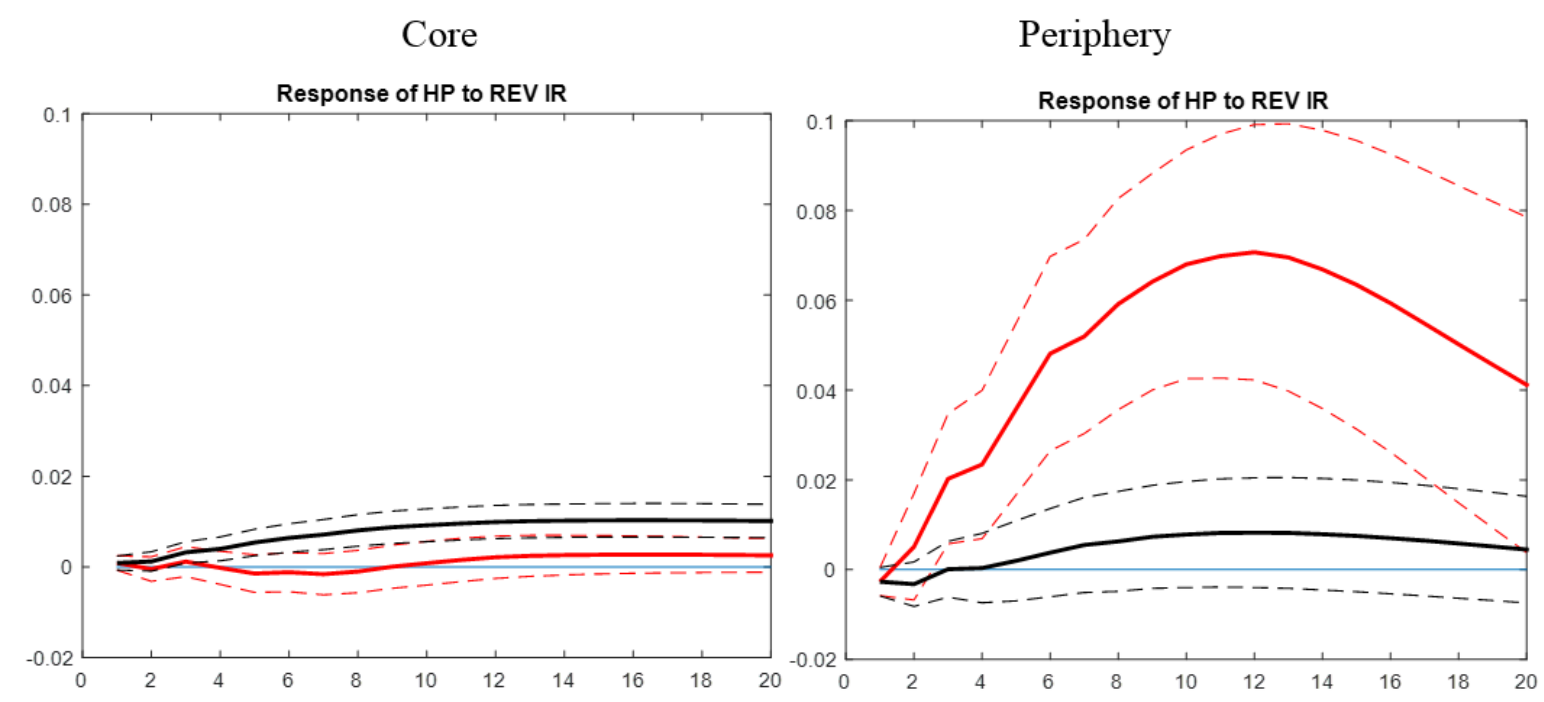

Notes: The estimation period ranges from 1Q1992 to 2Q200\%. The graphs show the responses of non-fundamental house prices to a 1-standard deviation positive shock to the reverse of the interest rate (monetary easing). Red solid lines show the responses in the mortgage market $\left(M_{i, t}=0.75\right)$; red dotted lines show the upper and lower bounds for bootstrapped $90 \%$ confidence intervals to the corresponding responses. Black solid lines show the response in less developed mortgage markets $\left(M_{i, t}=0.25\right)$; black dotted lines show the upper and lower bounds for bootstrapped $90 \%$ confidence intervals to the corresponding responses. 


\section{Figure 16: Smoothed Taylor Rule Rate}

Core

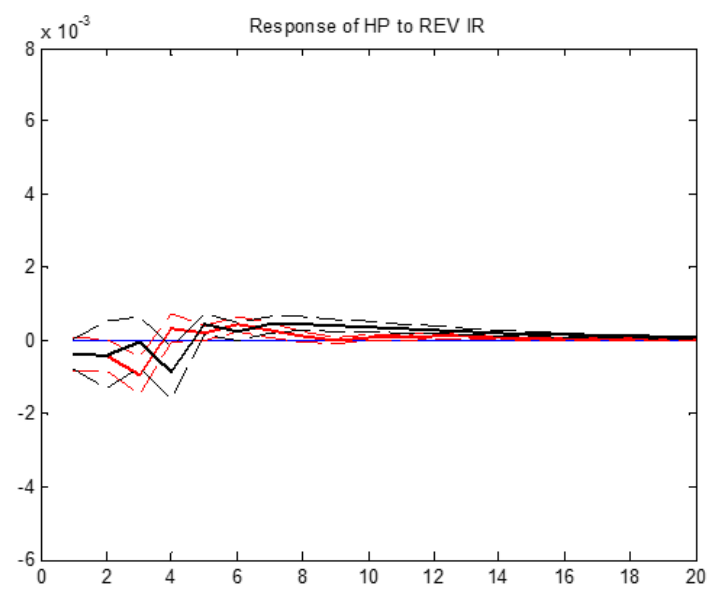

Periphery

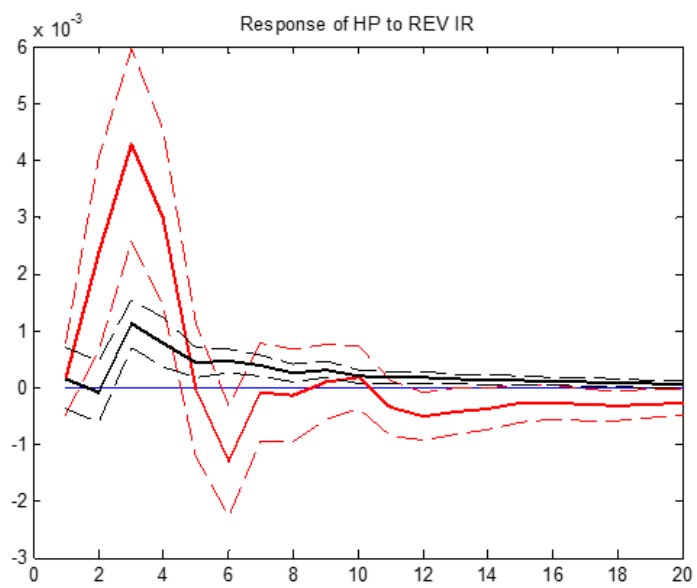

Notes: The estimation period ranges from 1Q1992 to 2Q200\%. The graphs show the responses of non-fundamental house prices to a 1-standard deviation positive shock to the reverse of the interest rate (monetary easing). Red solid lines show the responses in the mortgage market $\left(M_{i, t}=0.75\right)$; red dotted lines show the upper and lower bounds for bootstrapped $90 \%$ confidence intervals to the corresponding responses. Black solid lines show the response in less developed mortgage markets $\left(M_{i, t}=0.25\right)$; black dotted lines show the upper and lower bounds for bootstrapped $90 \%$ confidence intervals to the corresponding responses. 